Portland State University

PDXScholar

Dissertations and Theses

Dissertations and Theses

Winter 1-17-2014

\title{
Self-Efficacy in Low-Level English Language Learners
}

Laura F. Blumenthal

Portland State University

Follow this and additional works at: https://pdxscholar.library.pdx.edu/open_access_etds

Part of the Applied Linguistics Commons, Bilingual, Multilingual, and Multicultural Education Commons, and the First and Second Language Acquisition Commons Let us know how access to this document benefits you.

\section{Recommended Citation}

Blumenthal, Laura F., "Self-Efficacy in Low-Level English Language Learners" (2014). Dissertations and Theses. Paper 1622.

https://doi.org/10.15760/etd.1621

This Thesis is brought to you for free and open access. It has been accepted for inclusion in Dissertations and Theses by an authorized administrator of PDXScholar. Please contact us if we can make this document more accessible: pdxscholar@pdx.edu. 
Self-Efficacy in Low-Level English Language Learners

\section{by}

Laura F. Blumenthal

A thesis submitted in partial fulfillment of the
requirements for the degree of
Master of Arts
in
Teaching English to Speakers of Other Languages

Thesis Committee:

Lynn Santelmann, Chair

Kathryn Harris

Nike Arnold

Portland State University

2014 
(C) 2014 Laura F. Blumenthal 


\begin{abstract}
Accounting for differences in second language proficiency attainment is an important area of inquiry in the study of Second Language Acquisition (SLA). Accounts of the language acquisition process have generally come from cognitive or psychological perspectives, which view language learning as primarily an internal mental/emotional process, or from sociocultural or critical perspectives that emphasize the influence of the learner's social environment. Research on variability in language learning has also failed to take into account the learning experiences of low-level learners.

This study adopted a social-psychological perspective on language acquisition that focused on the role of self-efficacy in learning, and applied this perspective to understudied learners.

This study interviewed four low- to intermediate-proficiency English language learners (ELLs) from Mexico about their experiences and their self-efficacy beliefs about their ability to use their English. Their accounts of their experiences learning and using English were analyzed qualitatively and four major themes were found: the role of English language interlocutors, the participants' self-assessment of their abilities, structural obstacles to learning, and the participants' experiences of and responses to challenges. The results also explored students' expressions of self-efficacy, and the ways in which their levels of efficacy helped or hindered their ability to successfully engage in interactions with English speakers.
\end{abstract}


Table of Contents

Abstract....................................................... i

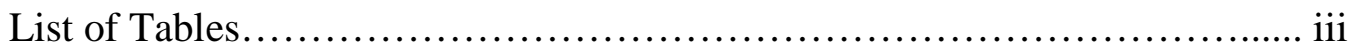

Chapter One

Introduction...................................................... 1

Chapter Two

Review of the Literature............................................. 6

Chapter Three

Methods............................................................. 27

Chapter Four

Results and Discussion............................................ 35

References................................................... 74

Appendix: Interview Guide........................................ 77 
List of Tables

Table 1

Comparison of self-efficacy and internal power..............................20

Table 2

Explanation of themes......................................................

Table 3

Participants' background information and description of themes...................... 


\section{Chapter One \\ Introduction}

In 2010, I spent some time in Morocco, living with a Moroccan family and studying Moroccan-Arabic at a language school. Everywhere I went in Morocco, people were amazed that I was able to speak any Arabic at all, and were eager to talk to me and compliment me on my language abilities, although my proficiency was quite low. I found that the experiences that I had interacting in every-day situations were just as or more helpful to me than the time that I spent in class, and I marveled at how helpful immersion is for language learning. Soon after I returned to the United States, I taught a community-based English class composed of very low-proficiency Spanish-speaking students, and I was struck by the differences between their language learning experience and my own. One of my students had lived in the United States for more than thirteen years and worked in an English-speaking workplace, yet she spoke almost no English. I was surprised by her situation, and wondered how it was possible that she could be immersed in English, have a clearly expressed desire to learn, and yet have acquired so little of the language, especially after I had found language-immersion to be so extremely conducive to language acquisition. As I thought about the differences between our experiences, it occurred to me that the social environment in which she operated likely bore little resemblance to the one that I had had. I doubted that when this middle-aged woman who spoke little English went to the grocery store that employees and customers gathered around her to listen to her speak and praise her for using a small amount of 
English. In fact, it seemed more likely that she might be met with a negative reaction for not having better command of the language.

As I began to think more about the impact of a learner's second-language (L2) social environment on language learning, I recognized that the environment could not fully explain differences in language-learning outcomes. Even if it were true that my student operated within a mostly hostile or discouraging English-speaking society, while I had encountered a friendly and encouraging Arabic-speaking one, there were others in the U.S. from similar backgrounds to my student who had been more successful. While it seemed that environment must play a role in how proficient a language learner becomes, it could not be the only factor.

Accounting for differences in L2 proficiency attainment is an important field of inquiry in the study of second language acquisition (SLA). After all, how can we claim to understand the process of language acquisition if we don't understand why some learners are successful, while others struggle or fail? In order to answer this question, many models of language acquisition have been developed that attempt to include and account for some or all of the interrelated variables that impact ultimate proficiency. These variables include: the age at which the learner began learning the L2, the amount and type of L2 exposure, amount and type of formal instruction in the L2, motivation to learn the L2, confidence in L2 abilities, learner attitudes toward L2 speakers and culture, identification as an L2 speaker, frequency of interaction with L2 speakers, and personal relationships with L2 speakers (Moyer, 2004). Within SLA, accounts of the acquisition have generally come from cognitive or psychological perspectives, which view language learning as primarily an internal mental/emotional process, or from sociocultural or 
critical perspectives that emphasize the positive or negative influence of the learner's social environment (Cervatiuc, 2008). Outside the field of SLA, theories of learning have also been developed. One, a social cognitive theory of human behavior developed by Bandura (1986), takes into account the influences of cognition, affective responses, and the social environment on learning in general.

Social cognitive theory can give us insight into variability in second language acquisition because it introduces a new construct into the explanation of learning outcomes: perceived self-efficacy. Through perceptions of self-efficacy, learners recognize their own capabilities and ability to make use of their capabilities to succeed within a given learning context. Thus, self-efficacy takes into account both internal and external influences on learning: it acknowledges the power of a learner's social environment to shape his or her experiences and outcomes while not discounting the agency of the learner in their own learning process. As an agent, learners are responsible for actively shaping their own learning through the opportunities that they seek and the extent to which they persist in learning despite setbacks. At the same time, they must operate within a social environment that also structures their lives and determines their opportunities to some extent. A key element of the social environment when it comes to language learning is the learner's experiences and relationships with L2 speakers. In order to explore the interplay between the learner and their social environment and the relationship of these factors to proficiency, this study examined learners' reports of selfefficacy beliefs and their experiences when speaking their second language, English.

Part of the struggle to adequately explain the reasons for variable outcomes in learning has been that learners who fall outside of specific, well-studied populations are 
often overlooked in the research. Research on individual variation has generally focused on learners who have achieved high levels of proficiency (e.g., Rubin, 1975, Cervatiuc, 2009). These learners tend to have had strong academic backgrounds in their countries of origin, something that is by itself correlated with successful second language acquisition (Condelli, 2004). However, despite being heavily represented in the literature, these learners are not representative of the majority of learners in the U.S., who tend to be less highly-educated (Condelli, 2004)

This study investigated how a group of learners who are not often studied, low- to low-intermediate proficiency ESL students from low educational backgrounds, accounted for their own learning process, especially with respect to the way that they express perceptions of self-efficacy and to the English-language interactions that they have had outside of school. Within the review of literature that follows this introduction, research on psychological explanations for variations in language learning outcomes and selfefficacy is presented. Following that is a discussion of the treatment of socialenvironmental influences on language-learning within the study of SLA, and how selfefficacy can clarify these factors and set them in a context that recognizes learners' agency. This discussion is primarily focused on the work of Cervatiuc $(2008,2009)$, whose research on successful language learning as a product of learner agency within a problematic social environment raised questions that this study sought to answer.

Following the review of the literature, the methodology that was used to conduct this research will be explained, after which the results of this research will be presented and discussed. Following the results and discussion will be a brief conclusion in which 
possible applications of this research to language teaching are presented, limitations of this study are identified, and possibilities for future research are suggested. 


\section{Chapter Two}

\section{Review of the Literature}

\section{Psychological Approaches to Variation in SLA: Motivation, Confidence, and Self- Efficacy}

In order to acquire linguistic proficiency in a second language, learners must be persistent in seeking language learning opportunities. This persistence can be viewed as a function of the learner's level of motivation to acquire the target language. Indeed, early studies of individual variation in proficiency outcomes such as that of Rubin (1975), stressed the role of the learner's motivation to use the L2 in the attainment of L2 proficiency. Rubin suggested that a primary difference between successful language learners and less successful learners is that the successful learners were motivated to communicate in the target language and thus created opportunities to interact with L2 speakers. This conclusion placed the responsibility for seeking out interactions on the learner and ignored the role of the learner's environment. In that way, it recognized the learner's agency in the acquisition process, but failed to recognize other influential factors that stemmed from learners' social environments.

Other attempts to build a profile of the characteristics of successful language learners and models of SLA that better accounted for the role of learners' social context in their language acquisition were developed by Canadian contemporaries of Rubin. This research was spurred by social psychologists, such as Gardner(1985) and Clemént (1980), who sought to understand the socially situated nature of language learning and the psychological effect of the social environment on individual language learners. This body of research focused specifically on the motivational processes that determined 
learners' proficiency outcomes (Dörnyei, 2005). The interest in the effect of the social environment on language acquisition was prompted by attempts to promote EnglishFrench bilingualism in Canada in the context of historical tension between the Anglophone and Francophone Canadian populations. In order to facilitate FrenchEnglish bilingualism, researchers in Canada attempted to identify what factors led to variability in learning outcomes (Dörnyei, 2005).

One of the most important studies to come out of the Canadian SLA research of that time was Gardener and Smythe's (1975, as cited in Clément, 1978) model of L2 acquisition which identified motivation and anxiety as two key variables that determined the likelihood of an individual's successful acquisition of an L2. According to Gardner's (1985) model, developed from his earlier work with Smythe, motivation took two primary forms, integrative motivation, which was composed of a learner's desire to integrate into the L2 community, and instrumental motivation, which was the desire to learn an L2 to achieve some other goal, such as getting a job that required fluency in the L2. His formulation of motivation and the Attitude/Motivation Test Battery that he developed to measure learners' motivation and affective orientation to the target language have remained influential in SLA research (Dörnyei, 2005).

Clément (1978) attempted to identify which elements of Gardner and Smythe's (1975, as cited in Clément, 1978) model most strongly correlated with language learning achievement. To do so, he conducted a set of studies of Francophone high school students enrolled in English classes. Students were administered surveys containing questions which were correlated with 38 variables relevant to the achievement of L2 competence. The majority of the survey items were derived from Gardner and Smythe's 
attitude/motivation battery. Clément concluded that the variables that had the strongest influence on language learning were motivation, specifically integrative motive, which was derived from Gardner's model, and was defined by Clément as the "attitude toward the second language group and [the learner's] willingness to become like valued members of that group" (p. 78); the type and amount of contact students had with English speakers; and the affective variable of anxiety. At the time that Clément conducted his study, there was a considerable amount of interest in the role in the learning process of foreign language anxiety, defined as an affective variable that "can interfere with the acquisition, retention, and production of [a] new language" (MacIntyre and Gardner, 1991, p. 86). In response to his findings, Clément developed a new model of language acquisition that centered upon a construct that he called self-confidence.

As Clément conceptualized it, self-confidence was composed of both psychological-affective and social-environmental elements. The psychological elements were positive self-ratings of L2 proficiency and negative ratings of anxiety associated with speaking the L2 in class or in public. While anxiety can be a general personality trait that is exhibited by an anxious individual in a number of different contexts, Clément made clear that anxiety as it related to self-confidence in his model is situation-specific anxiety. Situation-specific anxiety is anxiety that "occur[s] consistently over time within a given situation" (MacIntyre and Gardner, 1991, p. 87). Because the construct of selfconfidence established in his model is correlated only with a learner's confidence in using an L2, and is not necessarily related to their general self-confidence or confidence exhibited in other contexts, it can be inferred that it is also a situation specific trait. The 
social components that impacted self-confidence were frequent contact with L2 speakers, and frequent use of the L2 outside the classroom.

Clément's self-confidence model of SLA provided a first step toward building a model of language acquisition success that accounted for both the qualities that the learner brought to the process of language acquisition and the influence of the learning environment. However, the construct of self-confidence has not been much used in recent decades. Outside of the field of second language acquisition, research on the influence of motivation and affective variables on achievement has developed a construct of self-efficacy. Self-efficacy shares some similarities with Clément's self-confidence, but is better-defined and more thoroughly studied. Self-efficacy theory is an outgrowth of Bandura's (1986) social-cognitive theory of human behavior, which seeks to account for the influence of both the traits, beliefs, and thoughts of the individual and the social environment within which people operate on a person's behavior. Within that framework, self-efficacy beliefs determine how individuals behave, how they interpret the effects of their behavior, and how they respond to their social environment.

Bandura defined self-efficacy as "beliefs in one's capabilities to organize and execute the courses of action required to produce given attainments" (1997, p. 3). Beliefs about self-efficacy stem from four major sources: mastery experiences, modeling, persuasion, and affective factors. Mastery experiences are personal experiences of success at a task or within a sphere of action, and are the most powerful source of efficacy information. People's perceptions of their abilities are increased following successes, provided that they believe that their own competence was responsible for their success rather than circumstantial or other factors outside their control. Mastery 
experiences can affect the learning of those that witness rather than personally experience them through modeling, or witnessing the successes of others. Successful models have the greatest impact on observers when the observers believe the model to be similar to themselves in terms of ability. Perceived similarity between model and observer leads the observer to believe that they might reasonably use similar strategies and achieve the same success. Another factor that impacts self-efficacy is persuasion, or the messages that others convey about their beliefs and expectations about one's abilities. There are two types of persuasion, positive and negative. The influence of either form of persuasion is dependent on the credibility of the person delivering the message in the eyes of the person receiving it, though negative persuasion seems to have a greater lowering effect on self-efficacy than positive persuasion has on heightening it (Bandura, 1997). Finally, affective factors, such as anxiety, that alter a person's emotional state also play a role in people's perceptions of their abilities.

Self-efficacy has some overlap with confidence, both as Clemént (1978) described it and as it is generally used, as a synonym for self-belief. Both self-efficacy and confidence are related to a person's expectations of what will happen as a result of their behavior. A confident person and a person with a high level of self-efficacy both have the expectation that their behavior will produce a positive outcome and that they will succeed in accomplishing what they attempt to accomplish. However, like Clemént's confidence, and unlike more general constructs such as self-worth, selfefficacy is situation specific. One's beliefs about one's linguistic efficacy or academic efficacy might be wildly different from those about one's athletic or social competencies. 
A major difference between Clément's self-confidence and self-efficacy is that the contact between L2 speakers and L2 learners in Clément's (1978) model is either positive or negative, it is unclear who bears responsibility for the quality of contact, and that quality of the contact is viewed as having a one-way causal effect on learning. This is an overly simplified model of human behavior and interactions that does not recognize variability in the way that learners respond to and interpret their social environments. Bandura's (1986) social cognitive account of behavior rests on the hypothesis that the variables that cause human behavior are interdependent and have reciprocal effects on each other, rather than a one-way causal relationship. He posited a model of triadic reciprocal causation in which variables that influence action are reduced to three: behavior; "internal personal factors in the form of cognitive, affective, and biological events; and the external environment" (Bandura, 1997, p. 6).

In addition to integrating the roles of the learner's agency and the social environment into explanations of the learning process, the construct of self-efficacy can also help to resolve an issue of circularity in the relationship that Clément hypothesized between acquisition, confidence, and quality of contact (1980). This issue was pointed out by Moyer (2004) in a study of phonological attainment among German L2 speakers. Moyer found that high ratings of "satisfaction with phonological attainment" and "selfrating of spoken German," both measures of learner confidence, had a significant relationship to "native-like" pronunciation, as did frequency of interaction with nativespeaker (NS) Germans (p. 74). However, there was some difficulty in picking apart these variables due to their interrelated nature. Do high-proficiency L2 speakers achieve highproficiency because of their confidence, or are they confident because they have achieved 
high proficiency in their use of their L2? Triadic reciprocal causation in the development of learners' self-efficacy beliefs resolves this issue. Learners approach a new domain of learning with a concept of how capable they will be at achieving it based on other experiences that they believe to be relevant, such as other language-learning experiences, or other academic experiences. As they continue in the new learning domain, they derive more efficacy information from their successes and failures as well as from the other sources that determine efficacy beliefs, such as modeling and affective factors. The new information that they get about their capabilities then influences their efficacy beliefs going forward, and can heighten or lower their perceptions of what they will be able to do. These perceptions, or the level of self-efficacy that a person has in regard to a specific task, are more highly correlated with accomplishment of the task than actual ability (Bandura, 1997). In other words, a person's success or failure at a given task may be more closely linked to whether they believe that they are capable of the task than to the task-related skills that they possess. For example, Bandura cited Collins' (1982) study of mathematical self-efficacy among school-children, which found that, "Mathematical ability contributed to performance, but at each ability level, children who regarded themselves as efficacious were more successful in solving mathematical problems than were children who doubted their abilities" (Bandura, 1997, p. 37). This finding does not suggest that competence and skills are unnecessary, just that they are not sufficient. "Competence can be undermined by a low sense of self-efficacy and render an otherwise capable individual unable to perform a task, whereas a heightened sense of efficacy may enable individuals to perform above the level of what might be predicted on the basis of previous performances" (Bandura, 1997, p. 58). Thus, the answer to the 
circularity problem is that yes, high performance is a result of self-belief, and also yes, self-belief is a result of high performance.

\section{Research on Interaction and the Social Environment}

Interactions between language learners and more proficient speakers are an important part of the process of language acquisition. Long (1996) reviewed research on the role of interaction in SLA and concluded that although there was some debate over whether interactions are a necessary component of L2 development, they have been shown to facilitate language learning. Interaction with proficient speakers of a target language allows language learners to develop their L2 competence because it "connects input, internal learner capacities, ... and output in productive ways" (Long, 1996, p. 452). Gass (2003) made a stronger claim for the role of interaction, stating that research has suggested that "conversation is not only a medium of practice, but also the means by which learning takes place" (p. 234).

Not all interactions are equally facilitative of language acquisition. Long described facilitative interactions as those interactions in which participants must negotiate for meaning. In negotiating for meaning, both learners and more proficient speakers must make "adjustments to linguistic form, conversational structure, message content, or all three, until an acceptable level of understanding is achieved" (1996, p. 418). Long went on to suggest that interactions are especially beneficial to learners when they contain "negotiation work that triggers interactional adjustments by the NS [native speaker] or more competent speaker" (p. 451). When proficient speakers make adjustments to their speech to accommodate the linguistic capability of a lower proficiency interlocutor, they are not only providing learners with linguistic input, they 
are ensuring that the input is comprehensible to the learner. Long provided evidence that the comprehensible input that proficient speakers produce is more helpful to learners' L2 acquisition than the unmodified input that learners would receive if more proficient speakers did not modify their speech. Speech modifications can take a variety of different forms, among them: speaking more slowly, stressing key content words, and elaborating speech (for example, through the use of full noun phrases rather than anaphora). Additionally, cooperative proficient speakers work to maintain the conversation, asking frequent questions and making repairs when needed. Thus, facilitative interactions require a great deal of accommodation and effort on the part of the more proficient speaker.

Although every interaction requires a partner, facilitative interactions require the availability of a more proficient speaker who is willing to make efforts to understand the learner and to produce language that the learner can understand. Unless the proficient speakers in learners' communities are willing to make the effort to engage learners in negotiation for meaning, English language learners (ELLs), even those in a predominantly English environment, may not be surrounded by opportunities to improve their L2 proficiency via interaction. Interaction research has often been conducted in a classroom context and failed to take the socially constructed nature of language use into account, viewing language acquisition as an individual cognitive process (Foster \& Ohta, 2005). The absence of attention to social context has resulted in the research not taking into account that learners may not live in ideal L2 communities filled with proficient speakers willing to engage in facilitative interactions 
Norton (2000) noted the lack of attention paid to the social realities of the language learning environment in which learners operate and that SLA "theorists have not adequately explored how inequitable relations of power limit the opportunities second language learners have to practice the target language" (p. 5). Although immigrant ELLs ostensibly live in an immersive English-speaking environment, they may in fact have few opportunities for interaction with proficient speakers due to their social position relative to the English-speaking community (Cervatiuc, 2009; Norton, 2000). In a review of research on the relationship of social context to language acquisition, Seigel (2003) noted that the status of a linguistic minority relative to a dominant linguistic group impacts learning outcomes of members of the minority as they attempt to acquire the L2. The amount and type of interaction that learners have with L2 speakers is determined, at least in part by their social status relative to the L2 community.

The experiences of participants in Norton's (2000) case study documented how limited immigrants' access to the English speaking community can be because of the way that society is structured. The women in her study worked at occupations that called for little use of English, in part because of their limited English proficiency skills. While the women's jobs were often their primary connection to the English-speaking community, they were frequently prevented from participating in workplace conversation because they had been assigned more solitary and less language-dependent tasks within the workplace. For example, one of the participants in Norton's study, Eva, reported that in her job at a fast food restaurant, she was given more physical jobs, such as cleaning and taking out the garbage. Not only did the work not provide opportunities to use English as she worked, she also felt that because the work that she did was "the worst type of work" 
at the restaurant, her coworkers "assumed [her] to be a 'stupid' person" and did not include her in workplace conversation (Norton, 2000, p. 62). Norton reported that the learners in her study often felt unable to make a space for themselves in workplace conversations, and felt marginalized by the NSs with whom they worked. The circular relationship between proficiency and interaction can limit opportunities that learners have to engage more proficient speakers in conversation: proficiency in English is a precondition to gaining access to English-language interactions, and yet it is the interactions themselves that facilitate proficiency.

Lack of proficiency is only one factor that can make interaction and integration into the target language community difficult for ELLs. The attitudes and orientations of proficient speakers towards language learners also influence the opportunities that learners have to engage in L2 interactions. Rather than being willing partners in negotiation for meaning, researchers have found that proficient speakers often avoid interactions with ELLs (Norton, 2000; Cervatiuc, 2009), or respond to ELLs negatively with "lack of attention, rudeness, anger, and deliberate misunderstanding" (Derwing, 2003, p. 557). Little research has been done on the impact of negative reactions from NSs to ELLs' attempts to initiate interactions, but it has been suggested that it may have an inhibiting effect on learners' motivation to engage in communication with proficient speakers (Clément, 1980).

\section{Agency and the Language-Learning Environment}

Because L2 interaction is an important component of the acquisition process, ELLs must seek out opportunities for interaction. The extent to which learners pursue L2 interactions is a contributing factor to the level of proficiency that they ultimately achieve 
in the L2. This raises the question of why some learners persist in attempts to engage L2 speakers in interaction while others do not, a question that self-efficacy can help to answer. Unfortunately, research on the role of self-efficacy in learning has not yet become as prevalent in the field of SLA as it has in other disciplines (Mills, Pajares, \& Herron, 2006). However, social cognitive interpretations of existing language acquisition research that attempted to assess the way that successful learners approach their learning process in the context of their learning environments, can give new insight to those findings. One such study is Cervatiuc's (2009) research on the strategies used by Canadian ELLs to persist in attempting to improve their English proficiency, which addressed learners' ability to continue to seek out interactions and persist in learning despite unpleasant interactions and non-ideal learning environments. Cervatiuc conducted interviews with immigrant ELLs who had achieved high proficiency levels and found that these learners had made consistent efforts to engage in interactions with NSs, despite initially having trouble gaining access to these interactions due to a lack of proficiency. Participants in the study were found to have "generated a counter-discourse" (p. 259), an internal monologue that helped them to maintain confidence and positive self-image in the face of marginalization and mockery from NSs. In their counterdiscourse they focused on the progress that they were making in acquiring English and compared their English skills to what they had been previously rather than against a NS model. The learners were also able to maintain a high self-image by positioning themselves as highly-skilled bilinguals, a perspective that was made possible because all the participants were part of Canada's "brain gain" wave of immigration, which was composed of highly-educated, skilled professionals. Cervatiuc concluded that if learners 
interacting with NSs "focus on their limited external power then their perceived inferiority as interlocutors may create debilitating anxiety, inhibition, frustration, and fewer opportunities for speaking the target language, which may in turn lead to limited communicative competence and more social marginalization" (p. 268).

Cervatiuc took a poststructuralist critical perspective to her research, yet social cognitive theory is very applicable to her work. She called upon locus of control, a concept related to self-efficacy to explain her findings. Locus of control is a component of Weiner's (1986, as cited in Graham \& Weiner, 1996) attribution theory of achievement. Attribution theory suggests that there are three dimensions of causality which people use to explain a success or a failure in a given endeavor, and that the attributions that people make impact the likelihood that they will persist in that endeavor in the future. The three dimensions are: locus, which refers to the origin of the outcome, and whether it originates internally or externally to the person; stability, whether the cause to which an outcome is attributed is stable and unlikely to change or unstable and likely to change; and controllability, the level of control that a person has over the cause to which they attribute an outcome. Graham and Weiner (1996) illustrated the effects of attributions using the example of aptitude. Aptitude is an internal, stable, and uncontrollable cause. Pride and self-esteem can be enhanced following a success and diminished after failure if the success or failure is attributed to an internal cause, like aptitude, but are not likely to be affected if an outcome is attributed to an external cause, such as luck.

Bandura (1997) criticized attribution theory because he believed that the three dimensions offered by attribution theory for explaining outcomes were two narrow, and 
that there are many more factors that influence the assessment of one's capabilities resulting from a given situation However, he suggested that the attributions that people make can be reflective of their levels of self-efficacy, because "people who have a high sense of efficacy tend to ascribe their failures to insufficient effort or unfavorable circumstances, whereas whose who regard themselves as inefficacious view their failures as stemming from low ability" (85). He also acknowledged that attributions, particularly those that relate to locus of control, have a direct relationship with self-efficacy, because they give people efficacy information which alters people's views of their own abilities. In addition to the relationship between self-efficacy and locus of control, selfefficacy also offers another way to view what Cervatiuc called the participants' internal power. (The constructs of self-efficacy and internal power are compared in Table 1.) Internal power is the label that she assigned to the force which helped participants to counteract the influences of being marginalized by society. She suggested that their internal power:

emerges from awareness and appreciation of the symbolic resources that they have brought with them into the new country and that no one can take away from them: the sum of their attributes, transferable skills, languages spoken, professional expertise, life experiences, and their absolute worth as human beings independent of the social environment that they live in. (p. 267)

Cervatiuc noted that most immigrants have "little external power (limited material resources and access to social networks, no meaningful employment, and little understanding of the environment)" but that participants in her study "chose to believe that their perseverance in continuing to speak [English], even under conditions of 
marginalization and trying to get access to social networks and meaningful employment, would eventually lead to success and participation.” (p. 267) Increased perseverance and the belief that successful outcomes are under one's control are functions of a heightened sense of self-efficacy, as "self-efficacious individuals view attainments as personally controllable [and] tend to ascribe their failures to insufficient effort or situational impediments" (Bandura, p.124). Because efficacious people believe that they are capable, they tend to be more resilient in the face of obstacles and setbacks, which they do not interpret as reflective of incompetence. Instead, they are more likely to increase their efforts in the face of obstacles due to the belief that outcomes are within their control.

Table 1: Comparison of self-efficacy and internal power

\begin{tabular}{|l|l|l|}
\hline & Self-Efficacy (Bandura, 1997) & $\begin{array}{l}\text { Internal power (Cervatiuc, 2008, } \\
\text { 2009) }\end{array}$ \\
\hline Sources & $\begin{array}{l}\text { Self-efficacy information is } \\
\text { derived from mastery } \\
\text { experiences, modeling, } \\
\text { persuasion, affective factors }\end{array}$ & $\begin{array}{l}\text { Internal power is derived from } \\
\text { transferable skills, languages spoken, } \\
\text { professional expertise, life } \\
\text { experiences, worth as human beings }\end{array}$ \\
\hline Persistence & $\begin{array}{l}\text { Self-efficacious learners are } \\
\text { persistent because they } \\
\text { believe that they ultimately } \\
\text { are capable of achieving their } \\
\text { learning goals. }\end{array}$ & $\begin{array}{l}\text { Learners who focus on their internal } \\
\text { power are persistent because they } \\
\text { believe that they ultimately are } \\
\text { capable of achieving their learning } \\
\text { goals. }\end{array}$ \\
\hline $\begin{array}{l}\text { Role of locus of } \\
\text { control }\end{array}$ & $\begin{array}{l}\text { learners with a low sense of } \\
\text { self-efficacy attribute failures } \\
\text { to a lack of ability, believe } \\
\text { that they cannot create a } \\
\text { different outcome. }\end{array}$ & $\begin{array}{l}\text { Learners who focus on their internal } \\
\text { power believe that they have control } \\
\text { over their language learning and that } \\
\text { they can create the outcomes that they } \\
\text { desire. }\end{array}$ \\
\hline
\end{tabular}

The role of self-efficacy in successful learning outcomes is also apparent in Cervatiuc's earlier (2008) study. In that study, she interviewed successful language learners to determine the ways in which these learners interacted with and shaped their environments in order to facilitate language acquisition. In addition to attending formal 
classes or working with private tutors, Cervatiuc found that participants used strategies to increase the linguistic content in their everyday environments by watching television in English with subtitles or using word a day calendars to build vocabulary while engaged in their daily activities. Cervatiuc also identified strategies that participants used to increase their opportunities to use their new language and develop their proficiency in their day to day lives: such as increasing the amount of language content in their physical environment by "seeking social interaction with NSs, cultivating extroversion/outgoingness, taking risks in speaking English, second language immersion, securing employment that requires a high level of communicative competence, and seeking communication with NS coworkers" (p.77). Although "willingness to take risks" is only listed as one of the strategies, all of the strategies require some degree of risktaking, and comfort with risk-taking itself requires a high sense of self-efficacy. People with high estimations of their own capabilities are more likely to take on new challenges because they believe that they will be able to successfully meet them. The strategies that Cervatiuc described are those of efficacious language learners, who put themselves into situations that demand use of the target language (sometimes, as in the case of taking on jobs that demand strong command of the L2, greater use than they recognize themselves to be capable of), and believe that even if they are not able to meet the demands when they first encounter challenges, that they will continue to improve until they can easily meet those demands.

Cervatiuc's $(2008,2009)$ findings are somewhat undermined by the lack of inclusion of unsuccessful ELLs in her research. The positive self-image and sense of internal power that validated her participants' status as legitimate speakers of the L2 and 
strengthened their persistence regardless of the reactions of NSs were derived from the status and successes that they had achieved in their countries of origin. Norton and Toohey (2001) also found that successful ELLs gained the access to members of the L2 community that they needed to become proficient speakers by relying on intellectual and social resources to create identities that were valued by members of that community. Participants in these studies judged themselves capable of accessing NS communities and power structures, perhaps because, as successful professionals, they already had experience negotiating and succeeding within similar social structures and institutions. This conjecture is supported by Cervatiuc's (2009) indication that many participants used the strategy of preserving their sense of worth in an interaction by focusing on their professional and educational achievements. Although Bandura (1997) clearly indicated that self-efficacy is a situation-specific trait, he suggested that self-efficacy beliefs are transferable to related areas. Pajares (1996) went further, to say that there are certain "transforming experiences," such as earning a PhD, that are so powerful that they give one a sense of mastery and competence that extends to many other aspects of one's life. It seems likely that the educational and professional successes that participants in Cervatiuc, and Norton and Toohey had experienced contributed to a high sense of selfefficacy in the domain of learning more generally or in the ability to set and achieve difficult long term goals, such as becoming proficient in another language.

\section{Understudied Learner Populations}

There have been oversights in research that seeks to further understand the relationship between learners, their social environments, and variability in proficiency outcomes in second language acquisition. First, research has tended to exclude learners 
who do not come from strong educational backgrounds in their countries of origin.

Bigelow and Tarone (2004) identified a need for more language acquisition research that is inclusive of undereducated learners, specifically low-literate learners. They noted that literacy impacts the way in which learners learn and process an L2 and that findings from studies that have dealt almost exclusively with highly educated participants may not be applicable to ELLs with no or low literacy, who make up a significant proportion of immigrant ELLs. In addition to a need for more research to be conducted on the ramifications of low literacy skills on the cognitive aspects of language learning, there is also a dearth of studies that examine affective variables among uneducated learners. Cervatiuc (2009) deliberately selected participants for her study that came from educated professional backgrounds in their home countries in order to see what factors led to language learning success among professional-class Canadian immigrants. Norton (2000) also noted that the women in her study had all received intermediate to high levels of education in their home countries. However, many immigrants to the U.S. do not come from a high-status, educated, professional, background, and yet many of them are able to acquire high levels of communicative competence in English. Do those learners express strategies and sentiments that are indicative of high self-efficacy beliefs in the way the participants in Cervatiuc's study did? If so, where do they derive those beliefs from, as they do not have the same kind of educational or professional backgrounds from which to draw a sense of competence and ability?

A second group of learners that has not been sufficiently accounted for in the research are learners that have not achieved high levels of English proficiency. When lower proficiency learners are overlooked by researchers, it is difficult to say with any 
certainty whether the qualities found in high proficiency L2 speakers have been the cause of their success. It is possible that learners who fail to successfully acquire an L2 attempt to use the same strategies as high-proficiency attainers, or are equally motivated and equally positively oriented towards the target language, yet some other factor prevents them from achieving the levels of acquisition as their more fluent peers. Including lower proficiency learners would tell us more about whether these learners develop similar strategies to facilitate language learning.

Finally, some learners come from ethnic backgrounds that make it more difficult for them to fit into the mainstream L2 community than others. The majority of successful language learners in the research of Cervatiuc (2009), Norton (2000), and Norton and Toohey (2001) were not members of visible minority groups. Research on accent-based discrimination has found that visible minorities with accented speech reported more experiences of discrimination from NSs than non-minority NNSs (Derwing, 2003), suggesting that visible minority status may cause some immigrants to experience more marginalization and rejection from NS communities than others. Norton and Toohey noted the lack of visible minority NNSs in their research and commented that, although the "good language learners" portrayed in their article, had been able to gain access to NS communities, "we wonder what data we would have collected had [the learners] not been blonde and white-skinned, slim, able-bodied, well dressed and attractive to Western eyes" (2001, p. 318).

\section{Mexican Immigrants as English Language Learners}

In order to gather more information about the role of confidence in interactions among ethnic minority learners from low educational backgrounds, adult immigrant 
ELLs from Mexico were selected as the target population for this study. Mexican nationals represent the single largest immigrant community in the U.S., accounting for $29.9 \%$ of the total foreign born population in the United States according to 2009 U.S. census data (Pew Hispanic Center, 2010). According to this Pew Hispanic Center report, they become proficient in English at lower rates than immigrants from other Spanishspeaking countries: the report found that $71 \%$ of first-generation Mexican immigrants "say they speak English just a little or not at all” (Hakimzadeh \& Cohn, 2007, p. 18). The same report found that length of residency in the U.S. and level of education were the two factors most correlated with English acquisition, and suggested that the lower rates of English fluency among Mexican immigrants is due to their being the least likely to hold a college degree among the Spanish-speaking immigrant groups included in the study.

Whether or not they have achieved fluency in English, the Pew report noted $92 \%$ of "Spanish-dominant Hispanics" indicated that they believed that English was necessary for success when asked "whether adult Latinos 'need to learn English to succeed in the United States, or [if they] can ... succeed even if they only speak Spanish,"” (Hakimzadeh \& Cohn, 2007, p. 7). Many non-English speaking Mexican immigrants also find that their daily lives require them to further develop their English skills: about half of Mexican immigrants have jobs in workplaces in which some English or mainly English is spoken (Hakimzadeh \& Cohn, 2007). As a result of both the belief in the importance of English and the demands of work-life in the United States, large numbers of Mexican immigrants attend English language classes in an attempt to learn English. This study will explore how the self-efficacy beliefs and English-language interaction 
experiences of learners from Mexico might offer some explanation for the contradiction between the belief in the importance of English and the low proficiency outcomes of the learners.

\section{The Current Study}

This study had two goals: The first was to gather learners' accounts of their interaction and language learning experiences and evaluate them on the basis of what they reveal about the participants' efficacy beliefs. The second was to investigate whether there are differences in the way that lower- and medium-proficiency learners respond to and assess their English language environment, and whether differences relate to self-efficacy beliefs. In order to explore these topics, this study attempted to answer the following research questions:

1. What type of self-efficacy beliefs do lower- and medium-proficiency immigrant ELLs from Mexico express regarding their language proficiency and attainment?

2. What influences do learners' self-efficacy beliefs have on their perceptions of and responses to the English-language environment in which they live? 


\section{Chapter Three}

\section{Methods}

\section{Overall Design of Study}

This study differs from most self-efficacy research in that it is qualitative and somewhat broadly focused. Studies of self-efficacy have, for the most part, been very narrowly focused and have asked participants to evaluate their levels of self-efficacy for a given task using Likert scales (Schunk, 1991). In an overview of self-efficacy research in the study of academic motivation, Schunk pointed out the emphasis on quantitative research and identified the need for qualitative research, which "might include fewer subjects [but] would yield rich data sources for examining the role self-efficacy plays" (1991, p.226). This was an exploratory qualitative study predicated upon the constructivist view of knowledge creation (Croker, 2009). Interviews were selected as the data collection method for this research because they provided access to the nature of participant experiences as they were constructed and interpreted by the participants themselves (Richards, 2009). This approach is in keeping with the goal of qualitative research, which is to illuminate individuals' experiences, rather than to establish objective truth, and with constructivism, which holds that there is no objective truth, but rather multiple truths that are created by individual.

As to the broad focus of this study, while Bandura doubted the validity of global self-efficacy beliefs and noted that the more general a measure of self-efficacy is, the less predictive power if has, he suggested that self-efficacy could be measured at an "intermediate level" of specificity that would apply to "a class of performances within the same activity domain under a class of conditions sharing common properties" (Bandura, 
1997, p. 49). In this study, participants were asked about their beliefs about their ability to engage successfully in interactions with English speakers as well as about their beliefs about their ability to learn English. The efforts that students make to interact in English can be considered to be within the same domain, whether those efforts involve attending classes or making opportunities to speak English to coworkers.

\section{Context of Study: The Community College ESOL and Literacy Programs.}

The participants in this study were drawn from two sources, community college ESOL classes and volunteer-taught classes within a literacy program at this community college. One of the primary functions of the literacy program is to help students who have been unable to test into the next level of ESOL after taking a class twice, often due to poor literacy skills. Many students that lacked higher levels of education in their home countries have great difficulty in moving beyond Level 3, an intermediate level at the community college, due to inadequate literacy skills. At the college that participants attended, ESL instruction focuses more heavily on reading and writing skills and college preparation beginning at Level 4 (High-intermediate). Thus, many students are unable to progress past Level 3 and either stop taking classes or take literacy program classes. These students may not continue to take regular ESOL classes until they have passed the test to advance to the next level, and literacy program classes help them do that. The literacy program also serves students who were unable to enroll in regular classes because class space was unavailable, whose schedules are incompatible with regular class offerings, and who are enrolled in regular classes but who also benefit from attending literacy program classes. Of the four students that participated in this study, three were drawn from literacy classes, and one was enrolled in regular classes. 


\section{Participants}

In this study, four Spanish L1 Mexican immigrants, Alexa, Miguel, José Manuel, and Leonardo were interviewed (All of the participants are referred to by the pseudonyms that they selected). All the participants had been in the United States for at least three years and had arrived in the U.S. after the age of 20. The decision to focus on ELLs from a single country in this study was made in order to control for differences in cultural background that may impact learners' interactions or responses to American culture. Additionally, because culture can impact the way that individuals interpret events, it was important to control for the ways that culture influences attributions and self-beliefs by focusing on learners from the same cultural background. All of the participants were enrolled in English classes at the time of the study, which was an indicator of their intent to acquire English. Two of the participants were at the high-beginner ESOL level, as measured by a standardized CASAS test. The other two participants were in a beginner level class. Length of residency varied between the speakers from 3 to 26 years. The two beginner level students had the shortest and the longest durations of residency, thus proficiency level was not a function of length of residency.

None of the participants in this study were as proficient as the high proficiency speakers in Cervatiuc's (2009) study. Rather, the speakers that were considered proficient relative to the two beginner-level participants were at a high-beginner level, yet were judged by their instructor to have higher than average oral communication skills within that level. The decision to have these participants represent higher-proficiency speakers was made because the focus on the role of self-efficacy and interaction in acquisition necessitated controlling for other factors that are strongly correlated with high 
English-language proficiency. One of these is immigrants' level of education, which is highly correlated with English acquisition in the Mexican immigrant population (Hakimzadeh \& Cohn, 2007). Because of the relationship between educational level and proficiency, the participants recruited for this study possessed no higher degree than a high school diploma.

\section{Interviews}

A set of questions about the frequency with which participants engage in Englishlanguage interactions with more proficient speakers, their self-ratings of their proficiency in English, the level to which they seek out or avoid interactions, their reasons for seeking out or avoiding interactions, and their self-appraisal of their English proficiency skills in comparison to their personal goals and to their peers was created (Appendix). The first part of the interview consisted of semi-structured questions about participants' experiences with and feelings about interaction. Participants were asked to think of the most recent English language interaction in which they engaged, asked about the nature of that interaction (who they interacted with, when and where the interaction took place, and what the purpose of the interaction was), and then asked about their feelings about the interaction. They were then asked if they thought that the most recent interaction that they just discussed was typical of most of their interactions or unusual and asked to explain why. A pilot interview was conducted prior to refine the questions that were used in the study.

\section{Data Collection Procedures}

Participants were recruited by visiting their classes. Spanish-speaking students who were interested in participating were asked to fill out a short recruitment survey, and 
were contacted if they were from Mexico, had been in the Unites States at least three years, and had received no higher degree than a high school diploma.

Oral interviews were used for this research so that participants' literacy levels did not obstruct their ability to express their thoughts and feelings about interaction. The interviews were conducted in Spanish so that both higher and lower proficiency learners were able to express themselves in the language in which they are most fluent. Many studies of English-language acquisition are conducted in English, which leaves a significant part of the ELL population under-researched. The interviews were conducted by the researcher, with a Spanish-English interpreter present to translate between the researcher and the participant. The interpreter had completed a certificate program in Spanish-English interpretation and translation and was given additional guidelines by the researcher relating to confidentiality and to the prioritization of the participants' comfort throughout the interview.

Individual 40-60 minute semi-structured interviews were conducted with the participants using the interview guide (Appendix II). The interviews were recorded and the English portions were transcribed. After transcription, the audio for the interviews and the interview transcripts were given to another fluent Spanish-English bilingual who listened to the interviews in their entirety and checked the written translation for accuracy.

\section{Data Analysis}

Once the data was collected and transcribed, it was coded to identify themes in participants' reports. The coding was an iterative process, in which the coding system was revisited and revised several times. There were certain themes that were anticipated 
prior to the coding, as the interview guide had been constructed to focus on particular topics. These themes were confidence, the influence of role models, positive and negative experiences interacting with proficient English speakers, learners' selfassessment of proficiency, and successful and unsuccessful experiences that learners had had using English. However, an initial review of the data revealed that a number of those themes were not pursued by the participants, while two unexpected themes emerged that occurred across multiple interviews, which were obstacles to learning and creating opportunities to learn. A total of twelve themes that appeared across all of the participants' interviews were identified in the initial process: comfort, confidence, familiar/supportive interlocutors, goals, models, negative experiences, positive experiences, obstacles, evaluations and reactions of others, self evaluations, making opportunities and progress. The data and initial codes were reviewed by a peer to verify that the coding process was consistent and logical. Following the reviewer's recommendation, a number of these initial codes were consolidated, especially where there was a great deal of overlap and the two codes were conceptually similar. An example of this consolidation was that the data coded as "progress" was added to selfevaluation. The coded data were reanalyzed three more times and the number of themes was ultimately further reduced to four, two of which, self-evaluation and interlocutors, had both a positive and a negative component. These themes, listed with descriptions and examples in Table 1, below, were the role of English-speaking interlocutors in the learning process, learners' self-assessments, challenges, and obstacles. The themes will be further discussed in the results and discussion section. 
Table 2: Explanation of themes

\begin{tabular}{|l|l|l|}
\hline Theme & Description & Example \\
\hline $\begin{array}{l}\text { English-speaking } \\
\text { interlocutors }\end{array}$ & $\begin{array}{l}\text { Participants referred to the } \\
\text { impact of the people with whom } \\
\text { they spoke English on their } \\
\text { learning or feelings about using } \\
\text { English. }\end{array}$ & $\begin{array}{l}\text { Since the first time they } \\
\text { [coworkers] have been really, } \\
\text { really nice with me they have } \\
\text { made me feel really confident as } \\
\text { if I were part of their family. - } \\
\text { Alexa }\end{array}$ \\
\hline Self-Assessment & $\begin{array}{l}\text { Participants made a statement in } \\
\text { which they evaluated themselves } \\
\text { as English speakers or the } \\
\text { progress that they had made in } \\
\text { English. }\end{array}$ & $\begin{array}{l}\text { Sometimes compared to the other } \\
\text { students I think that for the time I } \\
\text { have been here in the United } \\
\text { States the other people have been } \\
\text { here for perhaps two or three } \\
\text { months and they speak better } \\
\text { English. -José Manuel }\end{array}$ \\
\hline $\begin{array}{l}\text { Structural } \\
\text { obstacles to } \\
\text { learning }\end{array}$ & $\begin{array}{l}\text { Participants referred to the } \\
\text { constraints that their work or } \\
\text { family responsibilities put on } \\
\text { their ability to study English. }\end{array}$ & $\begin{array}{l}\text { I went to [community college] for } \\
\text { some months, for almost a year, } \\
\text { in 2000, but had to stop } \\
\text { attending the classes because } \\
\text { they changed my work shift. - } \\
\text { Miguel }\end{array}$ \\
\hline $\begin{array}{l}\text { Experiencing and } \\
\text { responding to } \\
\text { challenges }\end{array}$ & $\begin{array}{l}\text { Participants referred to a situation } \\
\text { in which lack of proficiency } \\
\text { created difficulty, or to strategies } \\
\text { for dealing with such a situation. }\end{array}$ & $\begin{array}{l}\text { But sometimes, when [people } \\
\text { talk] too fast, or when they are } \\
\text { talking about things I don't } \\
\text { know, I, I guess stare at the } \\
\text { ceiling. -José Manuel }\end{array}$ \\
\hline
\end{tabular}

\section{Reliability}

One of the potential reliability problems in this study was that the data analysis was based on translations of participants' accounts of their experiences. In order to minimize misinterpretations that could lead to flawed analysis, the audio and the transcripts were reviewed after the translation by another Spanish speaker to determine if any of the translations were incomplete or inaccurate, and to correct the translations where such incidents had occurred. 
A second reliability problem that can arise in qualitative research is the possibility that the analysis and conclusions drawn are unique to the researcher and reflect the researcher's views more than the participants'. In order to confirm the validity of the codes, the data and codes were examined by a peer, who checked that the data were appropriately coded and that the identified themes made sense.

This research was made more trustworthy by having the interviews conducted orally rather than in writing. Some participants in this research had low literacy skills in Spanish as well as in English. Oral interviews made it possible for the participants to ask clarification questions if they did not understand what information is being sought, and to fully express themselves without being limited by their writing abilities. 


\section{Chapter Four}

\section{Results and Discussion}

The four participants in this study, Alexa, Miguel, José Manuel, and Leonardo were selected because they shared some similar biographical details. They were from the same country, had similar levels of educational attainment, and most of them had had similarly long residency in the United States. However, despite these similarities, each of them had had very different life experiences and different experiences as ELLs. The themes that emerged from the interviews represented factors that played an important role in the way that all the participants approached language learning and English interactions. The specific roles that the themes played in participants' language learning process and the ways that the participants discussed them varied. Sometimes differences in the way that participants talked about a theme were indicative of differences in their social environments. One example of this was the variation in the role of English-speaking interlocutors, who played a very positive and supportive role in some of the participants' lives, and a negative and inhibiting role in others'. The differences in the ways the participants discussed other themes, such as response to challenges, related more to the efficacy beliefs of the learner. A brief summary of the themes that emerged from each participant's interview, along with some biographical information can be found below in Table 3.

Below, a description of the themes that emerged from analysis of the interview data precedes the presentation and discussion of the reported experiences of each of the participants individually. Following the results and discussions of individual interviews 
is a more general discussion in which the participants are discussed as a group and the relationship of the data to the research questions is addressed.

Table 3: Participants' background information and description of themes.

\begin{tabular}{|c|c|c|c|c|c|}
\hline & $\begin{array}{l}\text { Length } \\
\text { of } \\
\text { residence } \\
\text { in the } \\
\text { U.S. }\end{array}$ & $\begin{array}{l}\text { Grade } \\
\text { completed } \\
\text { in Mexico }\end{array}$ & $\begin{array}{l}\text { Highest } \\
\text { community } \\
\text { college } \\
\text { English } \\
\text { level } \\
\text { completed } \\
\text { (in } \\
\text { progress) }\end{array}$ & Occupation & Themes \\
\hline Alexa & 14 years & 12 & 3 & $\begin{array}{l}\text { homemaker, } \\
\text { house } \\
\text { cleaner }\end{array}$ & $\begin{array}{l}\text { Positive role of English- } \\
\text { speaking interlocutors, } \\
\text { meeting challenges with } \\
\text { persistence, low self } \\
\text { assessment of } \\
\text { proficiency, high self- } \\
\text { assessment of ability to } \\
\text { learn }\end{array}$ \\
\hline Miguel & 18 years & 6 & (3) & $\begin{array}{l}\text { factory } \\
\text { worker }\end{array}$ & $\begin{array}{l}\text { Mixed role of English- } \\
\text { speaking interlocutors, } \\
\text { meeting challenges with } \\
\text { persistence, high self- } \\
\text { assessment of progress }\end{array}$ \\
\hline $\begin{array}{l}\text { José } \\
\text { Manuel }\end{array}$ & 26 years & 11 & (1) & $\begin{array}{l}\text { cook, } \\
\text { dishwasher }\end{array}$ & $\begin{array}{l}\text { Positive and negative } \\
\text { influences of English- } \\
\text { speaking interlocutors, } \\
\text { discouragement resulting } \\
\text { from challenges, low self } \\
\text { assessment of } \\
\text { proficiency, low self- } \\
\text { assessment of progress }\end{array}$ \\
\hline Leonardo & 3 years & 10 & 1 & $\begin{array}{l}\text { automotive } \\
\text { worker }\end{array}$ & $\begin{array}{l}\text { Meeting challenges with } \\
\text { persistence, high self } \\
\text { assessment of progress, } \\
\text { high self-assessment of } \\
\text { ability to learn. }\end{array}$ \\
\hline
\end{tabular}




\section{The Themes}

\section{Experiencing and responding to challenges and obstacles.}

The strongest of the emergent themes from the interviews were references that the participants made to the challenges in their lives that arise as a result of their low proficiency in English. Two broad categories were seen within the theme: challenges and obstacles. Challenges were specific situations that participants faced in which they could not understand or were not understood, such as wanting to order food in a restaurant, but being unable to read the menu or to communicate an order to the waiter. Structural obstacles were barriers to studying and learning English that arose due to the structure of participants' lives. The most common structural obstacles were demanding work schedules and family needs, or working in jobs that offered little contact with Englishspeakers.

\section{English-speaking interlocutors.}

The second most frequently recurring theme in the interviews was the role of English-speaking interlocutors. Experiences with interlocutors were both positive and negative. For the most part, the positive experiences represented interaction with supportive and friendly English-speakers whom the participants had come to know and to whom the participants had come to feel comfortable and confident speaking. These people were most often coworkers. Negative experiences with others mostly took the form of feeling judged or mocked by more proficient English-speakers for their lack of English proficiency, and they occurred with both strangers and people that the participant knew, such as coworkers and, in one case, family. 


\section{Self-Assessment.}

Self-assessing statements about participants' progress and level of proficiency often arose in the interviews. Students were also asked to assess their own skills relative to those of their classmates'. Although none of the participants considered themselves a fluent English speaker, self-assessments were for the most part quite positive: participants tended to describe their English speaking abilities in terms of the progress that they had made.

\section{Results and Discussion of Individual Interviews}

\section{Alexa.}

Alexa was a woman in her mid thirties who came to the United States fourteen years ago from a rural area in south-central Mexico, where she graduated from high school. In the United States, she had been doing part-time housekeeping work for the two years prior to the interview, but primarily had devoted her time since becoming a mother to caring for her three elementary-school-age children. She had enrolled in a community college English class 7-8 years before the interview, but had only been able to attend for one quarter because of housing issues and the birth of her oldest child. A few years prior to the interview she had enrolled in a special 6-month English program for mothers that she completed. She returned to community college English classes three months prior to the interview.

Although she had not taken many formal classes during her time in the U.S., Alexa had been able to enter back into ESOL classes at a low-intermediate level, which she had just completed at the time of the interview. She credited her proficiency gains 
outside of school to the fact that she spoke English as often as possible, the fact that her children were in school, and to her efforts to seek out English-language media. (All of the participants' quotes are from transcriptions of the interpreter's translation of the participants’ words.)

I'm always looking for a way to learn. What helps me now is that my sons are attending a school. That has helped me a lot because together we read books in English. I try to watch tv purely in English, nothing else, no Spanish, so that I understand and listen to English. At home we speak Spanish because we don't want our sons to lose the language, but I am always trying to read in English, to watch TV, also trying to write. I haven't studied much in school, but watching $T V$, reading books; when I'm outside of the house, I'm also reading the signs in English, I'm always trying to practice, to talk to people in the street, it all builds up.

At work, Alexa spoke only English, as none of her co-workers spoke Spanish. She also spoke to people at her children's school and her children's doctor in English. Of the four participants, she spoke English in the most situations outside of the community college. Some of Alexa's greater exposure to the English-speaking community was a result of her role as an involved parent. Alexa's identity as a parent gave her access and membership to an English-speaking community that the others did not have. One of the other participants, José Manuel, was also a parent, but he was not the primary caregiver for his children. He was not able to be involved in their schools because of his demanding work schedule, and so he did not have the same access to an English-speaking social network that Alexa did. 
Alexa's involvement with the English-speaking community at her children's school was not the only reason that she was exposed to more English than the other participants, however. Alexa also put a lot of effort into creating opportunities for interaction and learning. In this way, she was using many of the same strategies as Cervatiuc's (2008) participants. She maximized the linguistic resources available to her in her environment the form of television and signs on the street, which gave her richer linguistic input. She created opportunities to learn and practice English in the ways that were similar to the ones that Cervatiuc identified among high proficiency Englishspeakers: she sought social interactions with English speakers, was outgoing and extroverted, found work in which she was required to communicate in English, and communicated with her English-speaking coworkers.

In her interview, the theme that Alexa touched on most frequently was that of interlocuters, specifically the good experiences that she had had speaking English and of the kindness of English speakers that she had encountered. She reported few challenges and emphasized having a positive attitude in the face of challenges. Her view of her own progress was mostly very positive.

\section{Interlocutors.}

The strongest theme to emerge from Alexa's interview was the effect of encouraging and supportive English-speaking interlocutors on her language acquisition process. Alexa primarily interacted with people in English in two settings: at work, and at her children's school or doctor's office. In those places, she reported that she felt comfortable speaking to people, although in her children's school she was more likely to plan in advance what she wanted to speak about, and sometimes in the doctor's office she 
asked for an interpreter. Alexa had close relationships with her co-workers, none of whom spoke Spanish. She said that she felt most comfortable speaking English with her co-workers because of "the confidence that they have given me, the trust." She said that her co-workers had been "really, really nice with her" since she began working at the job, and made her feel "as if I were part of their family." She had experienced this in earlier jobs as well, and believed that the co-workers she had had over the years had been one of the main reasons that she had been able to make progress in English and overcome difficulties:

There have been a lot of people that have been really nice and really patient. They have taught me little by little and also I had a lot of energy and I put a lot of energy into learning English, so little by little I was able to get over those uncomfortable feelings that I had at the beginning, mainly because there were a lot of people that were really helpful and also because of my energy, and in the end I would start understanding what they were telling me and how I had to do things.

Alexa's positive experiences with English speakers extended to strangers as well as familiar interlocutors. Alexa acknowledged in the interview that there will inevitably be not-so-friendly people in the world, but emphasized that her experiences have always been good:

I have always run into good people. Nobody has been mean to me or discriminated against me. On the contrary, whenever I talk to people I say, "I don't really speak a lot of English,” but people encourage me, and say, “No, you 
are doing great! That's really good!" So I have been really lucky that I have always found really nice people.

The social environment that Alexa described is very different from the one depicted by Norton (2000, 2001) and Cervatiuc (2008, 2009). Their research emphasized the marginalization that is often experienced by ELLs and the ways in which their acquisition of the language is often accomplished in spite of the dominant language community rather than because of support from within that community. By contrast, Alexa gave her coworkers a great deal of the credit for the progress that she had made in learning English. As will be seen in the discussion of the interaction experiences of the other participants, the level of support and encouragement that Alexa's coworkers gave her was higher than that received by any of the other participants, but all of the participants reported receiving some degree of support and encouragement from members of the English-speaking community.

Although Alexa expressed that she had been lucky in not having bad experiences, she also seemed to believe that some of the responsibility for avoiding bad experiences rests with the English language learner. When asked what advice she would give to people who have had bad reactions or negative experiences with English-language interactions, Alexa said that she would tell someone in that position that:

They have to see that as something that has to encourage them to learn the language and to study it so that the people can understand them, because this is the United States and it's an English speaking country. So they should always have to find a way so that this doesn't happen again. And it's always going to 
happen that there might be some people that are not as nice, but that has to be something that encourages them to keep studying the language and learning it.

This advice fits with Alexa's own strategies for responding to challenges, which emphasize the control and agency that she feels that she has.

\section{Challenges.}

It was difficult for Alexa to recall any bad experiences that she had had speaking English. When pressed to recall any incident that she might have ever had in which she felt uncomfortable speaking English, she recalled some of her first experiences living and working in the United States as a non-English speaker:

At the beginning at my workplace, there were not many people who spoke Spanish and they would only speak English, so I didn't feel really comfortable. For example, when they told me, "please do this or that" I wouldn't understand, so that made me feel very desperate because I couldn't understand what they were telling me to do.

When asked how she responded to that experience and overcame the feeling, Alexa said that she began learning English in response to that situation, and credited helpful and patient coworkers as well as her own energy that she put into learning for achieving a level of proficiency that allowed her to function in her job. The challenges that Alexa faced were ones in which she felt that her English proficiency was not at the level that it needed to be in order for her to meet the demands of life in the United States, and so, for her, the solution was to put in more effort and to become a more capable English speaker. The attitude that Alexa took toward meeting her challenges suggested a strong sense of self- efficacy. She attributed the difficult or "desperate" circumstances in which she 
found herself to her own lack of language skill and believed it to be within her control to alter her skill level and thereby avoid finding herself in that type of situation. Bandura detailed the way in which attributions are mediated by self-efficacy, and suggested that more efficacious individuals are more likely to "view attainments as personally controllable" (1997, p. 124). By contrast, a less efficacious individual might have responded to the dilemma of finding that her skills were insufficient to meet the demands of a new job by concluding that she simply did not possess the required abilities, becoming avoidant of situations that demanded more language skills than she possessed, and perhaps seeking work that demanded less knowledge of English.

\section{Self-Assessment.}

In assessing herself, Alexa did not speak of her abilities in the most positive terms. She repeatedly said that she does not consider herself to be very proficient in English, and when asked how she felt that she compared to others in her class, she said that she thought that she was in the middle. However, she had a goal of achieving fluency and saw herself as capable of achieving that goal.

"Since I started taking classes I have seen this as an opportunity so I have taken it with a lot of courage and energy until I am able to learn and speak English... and it's very hard because I have my kids, work, and my kids' school, but I know that if you want, you can do it and you cannot just let time pass by."

Alexa spoke of the energy that she possessed that helped her to learn English a number of times in the interview. She gave credit to her own energy and the help of others equally when describing how she had learned enough English to function in an Englishspeaking workplace, and advised that energy was necessary to overcome obstacles and 
pursue fluency in English. Alexa's words suggested that, while she may not have had high perceived self-efficacy for her English-language competence or her ability to meet the linguistic demands of every situation, she perceived herself as an efficacious learner. Bandura suggested that self-efficacy can be extended across domains insofar as success in a given task often corresponds to an individual's general self-regulatory skills. He defined self-regulatory skills as "generic skills for diagnosing task demands, constructing and evaluating alternative courses of action, setting proximal goals to guide one's efforts, and creating self-incentives to sustain engagement in taxing activities and to manage stress and debilitating intrusive thoughts" (1997, p. 51) Alexa's confidence about her future learning successes reflected a generally high perception of her own ability to successfully learn. This confidence might be a result of the success that she had already had and the learning strategies that she had developed, or it may have been related to some other emotional resources that she possessed. In the same way that Cervatiuc's (2009) participants were able to construct and maintain a positive and protective selfimage by focusing on their achievements as highly educated professionals, it is reasonable that Alexa might have derived a considerable sense of her own power and ability from the experience of having made it to the United States successfully, overcome struggles to find employment and housing as a new immigrant, and established a life for herself as a functioning member of an English-speaking community.

Vicarious experiences can be an important source of self-efficacy beliefs. However, successful models did not seem to play a major role in heightening the selfefficacy beliefs of the participants in this study. Alexa was the only participant who reported having highly proficient English speaking models who came from backgrounds 
that were similar to hers. When asked if the success of these others inspired confidence in her, she responded, "Definitely. If they can learn, then I can too." This statement of self-efficacy beliefs based on the experiences of similar models is an example of what Bandura called "social comparative inference" (1997, p. 87). In fact, Alexa's description of how she felt about seeing the achievements of others is almost identical to Bandura's: he wrote that observers who see others who are similar to themselves succeed "persuade themselves that if others can do it, they too have the capabilities to raise their performance" (1997, p. 87). However, while Alexa's vicarious experiences might have been a source of increased efficacy beliefs, it is important to note that they were not a prominent feature in her own account of her language acquisition process.

\section{Miguel.}

Miguel had come to the United States from a rural area in south-central Mexico eighteen years prior to the interview, at which time he was in his late 30s. He grew up in a village where there was no electricity and was only able to complete sixth grade in Mexico. Here in the U.S., he had worked in a factory for fourteen years. He had received two promotions there and had moved up to doing specialized, skilled work. Miguel had attended English classes sporadically since his arrival in the U.S. He had first enrolled in classes in 2000 and attended for about a year, but had to stop because of conflicts with his work schedule. Over the following decade, he was able to complete about 5 quarters of English at a community college, and had been attending classes for 3 months prior to the interview. Over the years he had developed strong oral English skills, but at the time of the interview was unable to progress beyond level 3 at the community college because he struggled with reading and writing. His progress in English had 
undoubtedly been hindered over the years not only by the difficulty in making time to attend classes, but also by his lack of formal education in Mexico. He recognized this as an obstacle to his acquisition of English in the interview: I was very hurt, because in Mexico, I didn't have the opportunity to keep studying. Although Miguel had not developed high level academic English skills and his proficiency was nowhere close to that of the "successful" learners in other studies, he had in many ways been quite successful, especially considering his lack of formal academic experience. Some of his success may be attributable to his seeking out a job which demanded higher English skills than he possessed and then using the linguistically rich environment of the new job to develop his skills. Participants in both Norton (2000) and Cervatiuc (2008) used a similar strategy to increase their language proficiency: they acquired jobs that required higher proficiency than they possessed, but that also offered opportunities to interact in English and so increase their language skills until they matched the demands of the work.

In his interview, Miguel most frequently brought up the challenges that he had experienced at work. The role of English-speaking interlocutors in Miguel's life was less positive than it was in Alexa's, but it was another theme that frequently emerged, along with a mostly positive self-assessment in which he focused on the progress that he had made.

\section{Challenges.}

As an English-language learner working in an exclusively English speaking environment, Miguel had faced many challenges in the attempt to perform his job successfully. The aspect of his work environment that he found most challenging was not being able to understand or be understood by his co-workers. One of the situations in 
which he had found it difficult to understand people at work was on the phone. It was more difficult for him to understand people on the telephone than face-to-face, and there was less opportunity for him to ask for clarification. When he described this problem, he said that one of his fears was that the person on the other side of the phone could be the boss and they could say, "Why is this person answering the phone? He cannot speak English.” That doesn't make me feel comfortable. Miguel's feeling of perhaps being found insufficiently proficient for his work might have been a side effect of working in a job for which his proficiency was slightly low. Although this can be a successful strategy, as discussed above, and for the most part had been helpful for Miguel, his knowledge that his language abilities were not quite sufficient to complete required tasks created a new problem of needing to appear more proficient than he was. He sometimes responded to the problem of not understanding by acting as if he had understood even when he had not:

Because they are speaking English and there are some things that I don't understand... Sometimes I say that "Yes I understood everything," but then I leave and I am still wondering, "What did they say exactly?” Sometimes that makes me feel bad, but I don't want to ask again the same question, "What did you say?"

Although he had not always understood others in his workplace, Miguel had often encountered work situations in which it was important that his co-workers understand him. As a result, he had developed strategies for clarifying his meaning and making himself understood: 
Sometimes I try to say the same thing a different way to see if they can understand what I mean. And sometimes if there is the opportunity to draw I make a drawing of what I am asking for or what I need.

Developing successful strategies, in this case communication strategies, builds selfefficacy, because the strategies give a learner knowledge about how to successfully handle novel situations (Bandura, 1997). Belief in one's ability to meet new challenges in turn raises one's willingness to take risks. The competencies that Miguel had developed in being able to communicate in situations for which he lacked the necessary language proficiency helped him to succeed and may also have been a reason for his success. In other words, the knowledge that he had been able to use those strategies to successfully compensate for insufficient proficiency prior to his most recent promotion may have contributed to his willingness and ability to take on a more challenging position in the company.

Miguel said that the position he had at the factory was one that he had been able to attain because he had improved his English skills. He felt strongly that speaking English is necessary in order to be successful, and that learners must not let challenges prevent them from learning. When he was asked what advice he would give to a person who had difficulty moving on from bad experiences or negative reactions from English speakers, he said that he would advise them to keep studying and keep talking in English so that it doesn't happen again because English means more opportunities, more advantages, and it's something good for you as a person. His words were reminiscent of Alexa's advice to see bad experiences as encouragement to try harder, and reflect a similarly persistent approach to meeting challenges. Alexa's challenges were caused 
mostly by internal factors, in that her bad experiences were ones in which she did not understand or she did not feel prepared to meet the linguistic demands of her environment. The sources of Miguel's challenges were more external. A major component of the situations that he had found difficult was the reactions that other people had had to his use of English. He had framed these situations as preventable given increased effort. That framing had the effect of making an external factor, the reactions of another person, subject to more personal control. While it is not possible for a person to control how others treat them, it is possible to exert control over one's own effort. Furthermore, if a person has determined that a situation can be improved by means under one's control and within one's capabilities it becomes possible for that person to bring about that improvement. Alexa's approach to dealing with problematic responses was similar to Miguel's, but given that she had reported a lack of trouble with dismissive interlocutors, her advice might have been more hypothetical. By contrast, as will be discussed in the next section, Miguel had found himself in situations in which he was dismissed and criticized for his lack of proficiency, yet persisted in striving to acquire more language and advance his career.

\section{Interlocutors.}

Miguel spoke Spanish with his family, neighbors, and friends, and English at school twice a week and at work. Miguel reported that he felt:

Most comfortable with the people that I know, because they understand that there are some things that I cannot say and they make an effort to understand and also the people here at school for the same reason. 
Though there are people at work that he felt comfortable talking to, his experiences of successful extended discussion in English had been rare:

There are not many, but perhaps one [instance of feeling very good about speaking English] could be when I'm talking to my coworkers at lunch. We eat together and have a talk and I feel like I understand them and they understand me. But sometimes with people outside, people I don't know, I haven't had the feeling of good conversation.

The lack of good conversation may have been partially due to Miguel's personality. Unlike the other participants in this study and in Cervatiuc's (2008), who tended to describe themselves as talkative, outgoing, or extroverted, Miguel did not consider himself to be a talkative person, even in Spanish, and reported that he is even less talkative in English.

Miguel had had mixed experiences with his English speaking co-workers. Overall, he related fewer positive experiences with English-speaking interlocutors than negative ones. Although he had found some people to be encouraging, he had also had difficult encounters, in which the person that he interacted with reacted negatively to his attempts to speak English.

Sometimes I feel that people are encouraging me, but sometimes, some people are discouraging. Because there are people that say, "You don't speak English very well, why are you working here?" That makes me feel bad. Like at work some people are trying to speak English and they complain, "Oh this person cannot understand us." That's discouraging. 
This is very much unlike the other participants, none of whom reported coworkers making explicit statements about their lack of English competence. In fact, for most of the other participants, English speaking coworkers were the participants' most frequent and preferred English-speaking interlocutors, as they were supportive of participants' efforts to learn. Miguel's work environment was in many ways similar to those depicted by Norton (2000) and Cervatiuc (2009). Rather than a safe and supportive space in which to learn and practice English, Miguel's workplace was an environment in which he needed to prove himself worthy of being present, or where he constantly needed to establish his "right to speak", to use Norton's terminology (1997, p. 411).

It is unclear what effect the unsupportive work environment in which Miguel operated had on his self-efficacy beliefs, but it can be hypothesized that the anxiety that he felt about being judged unfit to speak might be an affective factor that increased his doubts about his abilities and lowered his sense of efficacy. Miguel expressed anxiety and fear of potential negative reactions, even in situations where it was unclear whether he had ever actually been met with criticism or rebuff. For example, when he was asked to describe situations in which he felt uncomfortable speaking English and he spoke of his experiences with having to answer the phone at work (discussed above), there was no indication that his boss had ever actually called and been critical of his English. Rather, it was the fear of how people might be thinking about or judging him that made him feel uncomfortable speaking. As will be seen, the fear of the judgment of others was also a significant component of José Manuel's experiences of language learning. 


\section{Self-assessment.}

Miguel was able to see very clearly the progress that he had made in his English. Although he felt that he had not yet attained his goal of being a fluent speaker, reader, and writer of English, he felt that he was not very far from it. When asked if he believed that he was good at speaking English, he answered, Yes, I feel like I have learned a lot. One always learns a lot when you are having a conversation in English, and taking these classes is also helping me a lot. His answer reflected an evaluation of his own ability as an English speaker that was grounded more in his progress and achievement than in his proficiency as measured in school or in comparison to more fluent speakers. When asked how he felt that he compared to other students in his classes, he answered that he considered himself to be at about the same level as his peers: It's more or less the same, sometimes there are things that I know that the others don't, sometimes it's the opposite, and that's how I learn. Despite the fact that he reported receiving less social support for speaking English than the other participants, Miguel was able to build and maintain a sense of competence in English because he measured progress by an internal standard. That approach is similar to the one taken by Cervatiuc's (2009) participants, who maintained a sense of themselves as competent speakers in spite of mockery or judgment from more proficient speakers by focusing on the progress that they had made and comparing their current performance to past performance rather than to NS models. Similarly, the strategy may have made Miguel less vulnerable to the judgments that others expressed about his linguistic ability. 


\section{José Manuel.}

José Manuel was originally from a city in southwestern Mexico. At the time of the interview, he had lived in the United States for twenty-six years, and was in his fifties. He attended high school in Mexico but did not graduate, and had worked at cooking and dishwashing jobs in restaurants since he arrived in the U.S. He was married with two children, and was the primary breadwinner for his family. As a result, he had worked two jobs for most of his life. However, as he had gotten older, he had developed some chronic health conditions, which had caused him to reduce his work hours, and at the time of the interview, he had only one job, a dishwasher position in a medical care facility. The reduction in hours had given him more time to study English and he had been attending beginning-level English classes four days a week for five months. He felt that his medical conditions and his long work hours had been major obstacles that prevented him from being able to learn English, and hoped that with better treatment for his conditions and more time to study he would finally be able to learn.

\section{Challenges.}

Like Miguel, José Manuel's greatest challenge was not being understood by English speakers. For José Manuel, the experience seemed to give him a sense of powerlessness. Many of the experiences in his daily life were frustrating to him due to his lack of English proficiency, such as not being able to order what he wanted at a restaurant, to understand people on the phone at work, or to ask for directions. José Manuel did not report having developed strategies for making himself understood the way that Miguel had. Rather, when asked what he does when someone does not understand him, he replied: 
So sometimes I don't know if it's because I have diabetes or because of my age, but sometimes [when I feel like I don't understand or people don't understand me] I don't ask questions or I don't try to say things... Sometimes, when it's too fast, or when [people] are talking about things I don't know, I just stare at the ceiling.

José Manuel often mentioned his jobs and his health conditions in his discussion of the problems that he had had learning English. In his life, these had been stable factors that he had little control over and which he believed prevented him from being able to learn English. His view that his health and his work made language acquisition impossible was likely to have had a self-determining effect, because while a high perception of one's abilities does not guarantee success, the belief that one will be unable to succeed can ensure failure (Bandura, 1997). However, José Manuel had hope that there would be an improvement to his ability to learn English going forward, as he had begun working less and receiving better health care. It is possible that if the change in his life circumstances heightens his perceptions of his ability to learn he will be able to make more progress. In most of the challenging situations in which he found himself, José Manuel's primary strategy seemed to be avoidance, or, as he put it, when he has felt frustrated or misunderstood:

I say that's ok, never mind.

José Manuel described some encounters with English speakers who seemed exceptionally unhelpful, which will be discussed further in the section on his experiences with English interlocutors, and in those situations it might be easy to see why he would not want to 
persist in the face of rejection. However, when he was asked if he felt that people don't try to understand him, he answered:

Perhaps it's because of my accent. But I have seen some Chinese people and they don't shut up afterwards but I just don't, don't say anything else.

In saying that, he acknowledged that it is possible that people's unhelpfulness is a form of discrimination, but also that others in the same situation might exhibit more persistence. José Manuel was the only participant who did not emphasize the importance of persistence in the face of challenges, which is unsurprising, given that he seemed to have displayed the least amount of persistence in his learning. As persistence is a function of self-efficacy, his lack of persistence can be seen as an indication of a low perception of his ability to meet the challenge of understanding or making himself understood.

\section{Interlocutors.}

The experiences of interacting with people in English that José Manuel related in the interview were predominantly negative. He spoke often of feeling that people were judging him for not speaking English, and said that:

Some people in the United States have made fun of my age, and they say "How come you don't speak English at your age?”... Some people in Spanish or in English "You live here in United States too many years and you don't speak English, are you crazy?" And sometimes in Mexican, or in Latin, "That's loco” Miguel also reported feeling anxiety about the judgment of more proficient speakers, yet the anxiety seemed to be more debilitating and a larger deterrent to using English for José Manuel than it was for Miguel. This may have been due to the role of efficacy beliefs in mediating the impact of anxiety. If a language learner has a low sense of efficacy, he or 
she is more likely to believe that other people's reactions are mostly uncontrollable and that the only way to avoid bad interaction experiences is to avoid engaging in interactions with those people from whom one fears rejection or poor treatment. A more efficacious learner is more likely to respond the way that Alexa or Miguel did, by believing that there is a means to alter a situation that is within their control and seeking that solution.

José Manuel's experience of being criticized or mocked for his failure to acquire English had not been limited to interactions with strangers or coworkers. He was married with two sons and was the only member of his family who did not speak English. He said that he did not feel able to practice speaking English with his family because they make fun of him when he tries.

When I try to speak English at home, the people are always correcting me, saying, “No, no, no, you didn't say that right!"

My wife also speaks in English, but we don't speak in English because she is always correcting me, saying, "You don't know what you're saying! You make mistakes!”

In addition to being openly mocked or criticized, José Manuel also spoke of experiences in which he tried to approach and speak to people who displayed an unwillingness to engage, such as when:

I'm asking for directions and I'm showing somebody that I have the address written, or sometimes inside a building I am looking for the bathroom, and people are just pulling off saying, “No, no, I don't understand anything you're saying. José Manuel's interaction experiences with English speakers were similar to those that Norton $(2000,2001)$ and Cervatiuc $(2008,2009)$ described. However, it is important to 
note that it was not only or even predominantly NSs that made him feel that his English was inadequate. Instead, the people that were mocking and dismissive of his attempts to use English were often his own family members, and José Manuel spoke of being laughed at by other Spanish speakers who were proficient in English as well. Leonardo, discussed in the next section, reported having similar feelings about speaking English in front of Spanish-English bilinguals, and the issue will be further discussed in the description of the role that interlocutors played in his learning, below.

For most of the time that he had lived in the United States, José Manuel had worked in Spanish-speaking environments. The medical facility in which he was working at the time of the interview was the first workplace in which he had regular encounters with English speakers as part of his job. Although he was spending most of the day in the kitchen, where everyone spoke Spanish, he had the opportunity to interact with nurses and residents when he left the kitchen to deliver meals. José Manuel described his interactions with the nurses in very positive terms, and said that they were the people that he felt most comfortable speaking to:

At work everyone is really helpful, really good people. They always try to make themselves understandable and to understand what I am saying.

The people that work with me know that I am coming to the English classes, and they practice with me, and also because I have diabetes they are very caring, because they check my blood in the mornings and they also check my blood pressure so that makes me feel really good about it [talking to them]. And since my coworkers know that I don't speak English, they tell me I can try to speak English with them... So I have gotten to know them better and I feel more 
confident when I talk to them, so even though I know they know I make mistakes, I feel better about speaking English with them.

José Manuel did not indicate whether his English speaking coworkers were NSs or not, but given the medical care setting in which he worked, it is likely that English was a second language for many of them. Whether or not they were NSs, they represented a group of proficient English speakers to which José Manuel had been granted access, and whom he found welcoming and supportive of his efforts to learn the language. This contradicts the narrative of the immigrant struggling to learn in the face of rejection or dismissal from a NS community. Although that was certainly part of José Manuel's experience, as it was also part of Miguel's experience, it wasn't the whole story.

\section{Self-assessment.}

José Manuel's assessment of his own English skills was mostly negative, though he often expressed a determination to try and a desire to learn. In some respects, his low estimation of his skills accurately reflected his low level of proficiency. However, especially in the early stages of learning, it is often beneficial for a learner to estimate that his abilities are slightly higher than they are. There will inevitably be obstacles in any pursuit, and an optimistic sense of self-efficacy can help to protect a person from being discouraged by initial failures (Bandura, 1997).

José Manuel was not the only participant to negatively appraise his proficiency. Alexa also classified her proficiency as low, despite the fact that it was far higher than José Manuel's. However, it is possible for a learner to assess his or her own abilities as average or low, and yet believe strongly in their ability to improve those abilities, as Alexa did. Unlike the other participants, including Leonardo, the other beginner level 
participant, José Manuel did not seem to believe that he was making much progress in his English. In fact, he was the only participant who expressed that he felt that he was not improving:

Sometimes Ifeel a little bit discouraged because, for example, this week made me scared a little: people were asking me, "What have you learned?" and I couldn't really give an answer, but I am still going to try to speak English.

Perhaps because he did not recognize his own progress or achievements, José Manuel was also the only participant who compared himself unfavorably to the other students in his class:

Sometimes compared to the other students I think that for the time I have been here in the United States the other people [in my class] have been here for perhaps two or three months and they speak better English and also they are younger than me. But I really try, I really want to try to learn the language. Although Bandura claimed that vicarious mastery, the experience of witnessing others be successful at a task, can be an important part of learning, he noted that the influence of vicarious experiences is strongest when the successful model is perceived as having competencies and abilities that are similar to the learner (1997). José Manuel did not indicate the factors to which he attributed the other students' success, but he believed that the factors that prevented him from learning were external and uncontrollable ones, such as his health and the demands of his jobs, that would likely not have been shared by his fellow students. Because a belief that a model possesses greater abilities than oneself diminishes the potential helpfulness of that model, it can be inferred that believing that 
one faces obstacles that the successful model does not face would also reduce the ability of the model to heighten the self-efficacy of the witness.

\section{Leonardo.}

Leonardo was a man in his late thirties who had come to the United States from a large city in central Mexico three years before the interview. He was a skilled automotive worker who had entered his profession in Mexico fifteen years before he emigrated to the U.S. In Mexico he had been forced to leave school and work for a few years after he finished sixth grade, but had been able to return to school and remain through the second year of high school before beginning an apprenticeship in which he learned his trade. He began taking English classes seven months prior to the interview, and at the time of the interview was about to move up to level 2. For most of his time in the U.S., Leonardo had worked in an entirely Spanish-speaking shop, but at the time of the interview he had just gotten a new job in a place where people predominantly spoke in English, although Spanish was also spoken. He had moved to the new job because he wanted more opportunities to speak and improve his English, employing a similar strategy as the one used by Alexa, Miguel, and Cervatiuc's (2008) participants, namely of taking work that requires a high degree of communicative competence.

Leonardo mentioned obstacles to learning English far less than the other participants, as well as fewer challenging situations. He described a learning process that had relied more on classes and his own independent learning strategies than on interacting with English-speaking interlocutors. The strategies that he was using, such as listening to the radio only in English and watching English language movies with English subtitles, were those that Cervatiuc (2008) described successful learners using and also 
were similar to Alexa's. The theme that Leonardo touched on most frequently in his interview was self-assessment. He was at a point in his learning process where he had begun to see significant progress and felt encouraged by that progress.

\section{Challenges.}

At the time of the interview, Leonardo had recently overcome one of the aspects of living in an English speaking environment that he had found most challenging, which was not being able to speak enough English to get the things that he wanted in restaurants and shops. His ability to use English had produced new possibilities for him:

In the restaurants, I used to go to the restaurant and if I saw that the servers were American, I would just leave the place and go to a Mexican place, but now I don't mind, and I go to any restaurant, like Chinese restaurants.

These new opportunities had significantly improved the quality of his day to day life, and removed a lot of the daily frustrations that José Manuel described. The lack of problems and challenges that Leonardo reported may be due to the fact that he was interviewed at a time when he was seeing tangible rewards for his recent gains in proficiency. Leonardo had had experiences in which people had not understood him, as all the participants had, but he said that these experiences did not bother him.

When people don't understand what I say, I don't see that as an obstacle, I just think that I have to learn, because I have to be understood. Every time that I am not understood, I have to learn.

Leonardo's words reflected a similar approach to challenges as the one expressed by Alexa and Miguel. All three expressed that challenges must be met with persistence, which is the view of a person who believes that it is within his or her power to effect 
different outcomes with increased effort. This view of challenges is indicative of a high sense of self-efficacy.

\section{Interlocutors.}

Leonardo interacted with English speakers mostly at school, although in his new job he had also begun to speak some English at work. Despite the fact that he sought his new job because he wanted to speak English more, he said that he did not feel very comfortable speaking English with his coworkers, who were mostly bilingual English and Spanish speakers. He said that he generally felt less comfortable speaking English to or around other Spanish speakers than he did when talking to people who do not speak Spanish:

Because Ifeel they [Spanish-speakers] are judging me, or laughing at me. When there are two Spanish speakers and an English speaker, I feel more ready to talk to the English speaker than to the other person, because I feel I am being judged or the other person is laughing at me. That's what has happened to me.

In light of Norton (2000) and Cervatiuc's (2008, 2009) conceptions of immigrant language learners as struggling to establish themselves as worthy speakers of a language in a dominant NS society, it is interesting that Leonardo found speaking English to Spanish speakers a much more unpleasant experience than speaking to English NSs just as José Manuel had reported being mocked by Spanish speakers for his low English proficiency. These proficient English-speaking Spanish-speakers were perceived as stricter gatekeepers of the English language than English NSs by these two lowerproficiency, Spanish-speaking ELLs. This perception suggests that the way in which immigrant ELLs are marginalized and denied access to L2 interactions has more 
complexity and nuance than a simple dichotomy between NSs who control and limit use of their L1 and learners who struggle to break past those limitations.

Despite his discomfort in speaking English with other Spanish speakers, Leonardo's experiences speaking English had generally been very positive, and he said that people respond positively to him when he speaks English. As for people that had appeared judgmental or unencouraging, Leonardo seemed able to brush off their reactions. As he put it, some people give me a [bad] look, but I don't mind, they have to understand me. He did not indicate that he had a close relationship with any Englishspeaking people, but he had expanded his use of English and had become able to talk to more people about routine things in the course of his daily life:

So, in the last six months, without realizing it, I have been speaking English at the gas station, restaurants, shops. When they are talking about basic things, for example, “What I want," I've started talking more.

Leonardo and José Manuel had reached similar levels of English proficiency, yet José Manuel felt that he could not do the small language tasks that Leonardo had begun to feel able to take on. The difference in the men's English abilities may be related to the differences in their approaches to handling challenges and discouraging outcomes. While Leonardo was dismissive of the people who responded negatively to his attempts to speak English, José Manuel became discouraged by these reactions and would abort his attempts to communicate when he was met with rebuff. Being able to dismiss and persist in spite of negative outcomes is indicative of a more robust sense of self-efficacy, as was seen in the discussion on Miguel and Alexa's approaches to overcoming challenges, and as Cervatiuc (2008) suggested. 


\section{Self-assessment.}

Leonardo's assessment of himself as an English speaker was almost entirely positive. Although his level of proficiency remained quite low at the time of the interview, Leonardo was the only participant to compare himself favorably to his classmates, saying that he thought that his accent was better than that of his peers'. The topics that he raised most frequently in the interview were the progress that he was making in English and the goals that he had set for himself in his life in the United States. Ultimately, his goal was to learn English:

to get a better job, because with the English I know now I was able to get a better job, so if I learn more I will be able to get a better job [than this one].

Leonardo was confident that he would be successful because he saw his recent successes as signs that he was capable of achieving his goal and already making progress on the path that he had set for himself. Leonardo's status as a skilled worker who had trained and become proficient in a trade may have given him a high opinion of his ability to meet self-set goals and succeed in learning English.

\section{General Discussion}

The first research question, which asked what self-efficacy beliefs the participants expressed and the second, which asked how these beliefs influenced their responses to their English language environments, must be answered together because of the reciprocal influence between participants' self-efficacy beliefs and their environments. As was shown in the discussions of the participants as individuals, Alexa, Miguel, and Leonardo expressed much higher senses of self-efficacy in their ability to use English and in terms of their prospects for continuing to develop their proficiency than José Manuel 
did. The differences between the expressed self-efficacy beliefs of José Manuel and the others are intriguing given that he had the lowest proficiency of the three despite having been in the United States the longest amount of time. In general, length of residence is correlated with higher English-proficiency (Hakimzadeh \& Cohn, 2007). However, the long length of time that José Manuel had been in the United States may have ultimately have lowered his self-efficacy further and made it more difficult for him to learn, as he likely became more discouraged by his lack of progress as time passed.

The contrast between José Manuel and the other participants was most apparent in the differences in their responses to challenges. While the other three participants had encountered similar challenges to the ones that José Manuel had experienced, they had exhibited more persistence in continuing to study and use English and emphasized that they believed that persistence was necessary to learn. José Manuel was the only participant who did not discuss the importance of persistence to language learning, and reported that when he encountered difficulty in using English he tended to give up. José Manuel and Miguel both indicated that they feared that their English abilities were being criticized and that others were judging them as inadequate, but Miguel's response to those feelings was to learn more English so that he would not be as vulnerable to criticism, while José Manuel stopped trying to speak English with people who were critical of him.

It is possible that José Manuel was simply more vulnerable to negative persuasion than the others, but it is also important to note that the people who criticized and mocked José Manuel's English were not strangers or colleagues, but his family. The influence of persuasion on efficacy beliefs is dependent on how much credibility the recipient of 
feedback vests in the person delivering it (Bandura, 1997). It is therefore not surprising that José Manuel might have been very influenced by hearing his wife, whom he is close to and who knows him well, saying that his English is inadequate. However, José Manuel was similar to the other participants in that he did not blame the people that he interacted with for discouraging him or preventing him from learning.

Another place in which differences in the levels of self-efficacy expressed by the participants became apparent was in their self-assessing remarks. Leonardo rated his proficiency the most highly of the participants, despite being one of the lower-proficiency speakers. His extremely positive self-evaluation may have been due to the fact that he had been in the United States a relatively short period of time and had made rapid progress in the time shortly before the interview took place. Alexa and Miguel were more measured in their assessments of their ability overall and relative to their peers, but both of them recognized that they had learned a lot of English over the years and believed that they would continue to make proficiency gains in the years to come. Alexa, Miguel, and Leonardo all recognized that they had made progress, and were encouraged by the progress that they had made to feel that they were capable of achieving still more. In contrast, José Manuel was the only participant to express doubts about whether he was making progress. Despite his pessimism in regards to his progress, José Manuel still had hope for the possibility that he would be able to learn and expressed optimism for his chance of becoming a better English speaker in the future.

It is not possible to claim causation between José Manuel's low English proficiency and low self-efficacy, but one can infer that there is a relationship between the two variables, most likely a reciprocal one. It is likely that his low perception of his 
own ability to learn English was one of the factors that inhibited his learning, and that as time went by and his proficiency remained low, his sense of self-efficacy was further reduced.

For the most part, the low-proficiency participants in this study demonstrated efficaciousness in the same way that the high-proficiency participants in Cervatiuc's $(2008,2009)$ research had. They expressed that they felt that they were capable of surmounting obstacles that made learning English difficult, and discussed obstacles and challenges that they had already overcome. Just as Cervatiuc's participants exercised their agency and ability to reshape their social environments to be more conducive to language acquisition, so too did these low-proficiency ELLs arrange their lives so as to provide the maximum number of opportunities for learning. Additionally, most of these low-level learners maintained a focus on their own progress rather than engaging in fruitless and demoralizing comparisons of themselves with higher proficiency speakers, which was a component of the coping strategy that Cervatiuc's high-proficiency participants used to avoid becoming discouraged.

The English-language environments described by the participants differed from each other and also from the hostile, marginalizing one described by Cervatiuc (2008, 2009) and Norton $(2000,2001)$. There was a level of complexity in the participants' social worlds which cannot be reduced to a simple divide between powerful, often marginalizing NSs and powerless, marginalized NNSs. Not only did participants find support among the more-proficient speakers with whom they interacted, these more proficient speakers were not necessarily NSs. In fact, both José Manuel and Leonardo expressed more discomfort about speaking English with more proficient English- 
speaking Spanish-speakers than with the other English speakers in their lives. This is not to say that the English-speaking environments in which the participants operated were entirely supportive, facilitative, and unproblematic: with the exception of Alexa, all the participants reported that they had received unfriendly or critical responses to their use of English at some point. However, all of the participants but José Manuel said that they felt that the appropriate response to negative responses was to renew their efforts to improve their English to lessen the chances that they would experience those responses again.

\section{Conclusion}

\section{Applications to language teaching.}

Because self-efficacy beliefs play an important role in determining students' learning outcomes, it is important for second-language teachers to incorporate tactics into their classrooms that build students' sense of self-efficacy. This research suggests three ways in which teachers can do so: by incorporating students' families into the learning process, by helping students set goals and recognize progress, and by developing strategies to deal with obstacles to learning as they arise. These approaches are also supported by education research on the role of learner self-efficacy. The social cognitive approach to learning stresses the importance of making students aware that they possess agency as learners, and are able to exert control over and shape their learning process (Bandura, 1997). The recognition of agency is an important component of self-efficacy building, as students must believe that they are capable of achieving successful outcomes in learning. Students' sense of self-efficacy is increased when they learn how to set goals 
and develop successful self-regulating strategies (Bandura, 1997). These methods for raising students' self-efficacy fit particularly well in classrooms of adult ESL learners.

As José Manuel's experiences demonstrate, teachers must bring the family into the language-learning process. The feedback and attitudes of family members toward students' language use is likely to impact learners more strongly than that of strangers, and students may have more ability to alter the social environment within their families than they have to alter their interactions with strangers or coworkers. Students may have spouses or children that have higher English-proficiency than they do, and these family members must be positioned to help the learner succeed rather than to be discouraging or undermining. Teachers can help students create a positive family dynamic by discussing with their students ways that families can be supportive of students' learning, and by encouraging students to ask their families for the help that they need.

Like Alexa, Miguel, José Manuel, and Leonardo, students in adult ESL classrooms are usually attending classes of their own volition as a way to achieve personal language learning goals. Their presence in the classroom indicates that they believe that they will be able to benefit from the language instruction in the classes. However, students often set very vague long-term goals that focus on the desired end results of a learning process (Bandura, 1997). In a language-learning context, this happens when a student sets a goal such as 'becoming a fluent English speaker.' When students set goals that are too distant, it is difficult for them to see progress, and they can become discouraged or lose confidence in their ability to meet the long-term goal. Although fluency in English was the goal of all the participants in this study, the more 
efficacious participants measured their success in terms of the progress that they had made, rather than by how close they were to absolute fluency.

In order to bring students' focus to progress, teachers should assign their students or assist their students in setting "strategic agency goals," which are proximal goals that students achieve in the process of meeting their long-term objectives (Bandura, 1997). They allow students to develop their sense of agency as they can measure their progress and track what they have achieved through their own effort and ability. Although study has indicated that students report higher levels of self-satisfaction when they select their own goals, teacher-assigned goals have been equally effective in raising students' sense of efficacy (Bandura, 1997). Teachers could help students set appropriate goals in ESL classrooms by making course or lesson objectives explicit and encouraging students to monitor their progress toward achieving them. Teachers could help students to set their own goals by encouraging them to do as Leonardo did: to increase the domains in which they use English, and to track the expanding the number of situations which they can navigate in English as they do so.

Another component of raising students' self-efficacy is assisting them in developing self-regulating strategies for learning (Bandura, 1997). Self-regulating strategies are necessary for learning because, as Bandura pointed out, more is required for students to be successful in a class than ability or knowledge in the specific subjects covered in the class. Students must recognize the other components of successful academic outcomes, such as time-management, study strategies, and generally organizing their environment to make it conducive to learning. Teachers should address the need for students to develop their competencies in these areas by helping them develop plans for 
handling challenges when they begin a course of study. Teachers can also foster selfefficacy in students' ability to use self-regulating strategies by facilitating discussions of what strategies students have used, and particularly what strategies have been successful for them. Students are more likely to believe that a strategy will be effective for them if they see that it has been effective for someone that they perceive as a peer (Bandura, 1997).

\section{Limitations of this study and suggestions for future research.}

The biggest limitation of this study was that the number of participants in this study was small, and because they were only interviewed once it was not possible to get confirmation of the themes and interpretations developed from their accounts. A similar study undertaken with a larger number of participants and more interviews would be necessary to develop a better understanding of self-efficacy beliefs and how they affect learning experiences among this learner population.

Another difficulty resulting from the limited number of interviews conducted is that there are some questions that remain unanswered. One of these questions is what internal resources efficacious ESL learners such as the participants in this study draw upon in order to maintain their high level of belief in their own capabilities. Unlike the participants in Cervatiuc's $(2008,2009)$ research, none of the participants in this study had had the type of mastery experiences that high degrees and professional training represent when they arrived in the United States. However, their expressions of selfefficacy beliefs and the strategies that they developed to structure their learning environments were very similar to those of the participants in Cervatiuc's work. Future 
qualitative research on self-efficacy beliefs among adult ESL learners should address the question of the source of these learners' efficaciousness.

One of the goals of this study was to incorporate into SLA research groups of participants that are not often studied. It is important that the participants in language acquisition research are representative of language students. In this study, ELLs were able to express themselves and describe their experiences as English-learners and speakers in the language that they felt most comfortable using. It would be beneficial to our understanding of the lived experiences of ELLs, particularly lower-proficiency ELLs, if more qualitative research were conducted with learners in their L1s.

Finally, there is a need for more uniformity in how we model learning and motivational processes across the social sciences. Currently, as Pajares (1996) pointed out, there are many differing approaches to studying the role of self-perception and motivation in the learning process that incorporate in their models differently labeled constructs with overlapping definitions. Social cognitive theory and the construct of selfefficacy have become increasingly influential in approaches to learning and achievement among psychologists and educators, yet have had little influence in language teaching (Mills, Pajares, \& Herron, 2006). More self-efficacy research should be done within the study of second language acquisition.

\section{Final Remarks}

It is important to note that Alexa, Miguel, José Manuel, and Leonardo continue to attend classes and to increase their English language proficiency, and also that efficacy beliefs change as people have new experiences and develop new perceptions of their own capabilities. Their achievements prior to their interviews, as they were represented in this 
study, do not represent their final outcomes. Rather, this study serves as a snapshot of a moment in the participants' learning processes, which will continue to evolve throughout their lives. 


\section{References}

Bandura, A. (1986). Social foundations of thought and action. Englewood Cliffs, NJ: Prentice Hall.

Bandura, A. (1997). Self-efficacy: The exercise of control. New York: W.H. Freeman.

Bigelow, M., \& Tarone, E. (2004). The role of literacy level in second language acquisition: Doesn't who we study determine what we know? TESOL Quarterly, 38(4), 689-700.

Cervatiuc, A. (2008). Deconstructing the environment: The case of adult immigrants to Canada learning English. Journal of Identity and Migration Studies, 2(2), 67-86.

Cervatiuc, A. (2009). Identity, good language learning, and adult immigrants in Canada. Journal of Language, Identity, and Education, 8, 254-271.

Clément, R. (1978). Motivational characteristics of francophones learning English:

Predictive and descriptive aspects. Quebec: International Center for Research on Bilingualism.

Clément, R. (1980). Ethnicity, contact, and communicative competence in a second language. In H. Giles, W.P. Robinson, \& P. M. Smith, (Eds.), Language: Social psychological perspectives (pp. 147-154). Oxford: Pergamon Press.

Clément, R. \& Kruidenier, B. (1985). Aptitude, attitude and motivation in second language proficiency: A test of Clément's model. Journal of Language and Social Psychology, 4(1), 21-37.

Condelli, L. (2004). Effective instruction for adult ESL literacy students: findings from the What Works study. In What counts as evidence for what purposes in research in adult literacy, numeracy and ESOL: papers from the first NRDC International Conference. Retrieved from: http://www.nrdc.org.uk/uploads/documents/doc_54.pdf>.

Croker, R.A. (2009). An introduction to qualitative research. In J. Heigham \& R.A. Croker, (Eds) Qualitative research in applied linguistics (pp. 3-24). London: Palgrave Macmillian.

Derwing, T.M. (2003). What do ESL students say about their accents? The Canadian Modern Language Review, 59, 547-566.

Dörnyei, Z. (2005). The psychology of the language learner: Individual differences in second language acquisition. Mahwah, NJ: Lawrence Erlbaum Associates. 
Foster, P. \& Ohta, A.S. (2005). Negotiation for meaning and peer assistance in second language classrooms, Applied Linguistics, 26(3), 402-430.

Gardner, R.C. (1985). Social psychology and second language learning: The role of attitudes and motivation. London: Edward Arnold.

Gass, S.M. (2003). Input and interaction. In C.J. Doughty \& M.H. Long (Eds.), The handbook of second language acquisition (pp. 224-255). Malden, MA: Blackwell Publishing.

Graham, S., \& Weiner, B. (1996). Theories and principles of motivation. In D.C. Berliner \& R.C. Calfee, (Eds) Handbook of educational psychology (pp. 63-84). New York: Simon \& Schuster Macmillan.

Hakimzadeh, S., \& Cohn, D. (2007). English Usage Among Hispanics in the United States. Retrieved from Pew Hispanic Center website:

http://pewhispanic.org/files/reports/82.pdf

Long, M., H. (1996). The role of the linguistic environment in second language acquisition. In W. C. Ritchie \& T.K. Bhatia, (Eds.) Handbook of Second Language Acquisition (pp. 413-468). London: Academic Press.

MacIntyre, P.D., \& Gardner, R.C. (1991). Methods and results in the study of anxiety and language learning: A review of the literature. Language Learning, 41(1), 85-115.

Mills, N., Pajares, F., \& Herron, C. (2006). A reevaluation if the role of anxiety: Selfefficacy anxiety, and their relation to reading and listening proficiency. Foreign Language Annals, 39(2). 276-295.

Moyer, A. (2004). Age, accent, and experience in second language acquisition: An integrated approach to critical period inquiry. Clevedon, England: Multilingual Matters.

Norton, B. (1997). Language, identity, and the ownership of English. TESOL Quarterly, $31,409-429$.

Norton, B. (2000). Identity and language learning: Gender, ethnicity, and educational change. London: Longman/Pearson Education.

Norton, B., \& Toohey, K. (2001). Changing perspectives on good language learners. TESOL Quarterly, 35, 307-322.

Pajares, F. (1996). Self-efficacy beliefs in academic settings. Review of Educational Research, 66(4), 543-578. 
Pew Hispanic Center. (2010). Statistical Portrait of the Foreign-Born Population in the United States, 2009. Retrieved from http://pewhispanic.org/factsheets/factsheet.php?FactsheetID=69

Richards, K. (2009). Interviews. In J. Heigham \& R.A. Croker (Eds.). Qualitative research in applied linguistics (pp. 182-199). London: Palgrave Macmilian.

Rubin, J. (1975). What the "good language learner" can teach us. TESOL Quarterly, 9, 41-51.

Schunk, D. H. (1991). Self-efficacy and academic motivation. Educational Psychologist, $26(3 \& 4), 207-231$.

Seigel, J., (2003). Social context. In C.J. Doughty \& M.H. Long (Eds.), The Handbook of Second Language Acquisition (pp. 178-223). Malden, MA: Blackwell Publishing. 


\author{
Appendix \\ Interview Guide
}

\title{
Intro, Basic info questions
}

How many years have you lived in the U.S.?

What is your job? (Ask about job related skills if applicable)

When did you start doing that job, how did you know that it would be a good job for you?

Do you know any other languages besides English and Spanish?

If yes, how/when did you learn those languages?

\section{Habits of speaking English}

Do you think of yourself as a person who is more quiet, or more talkative (in Spanish)?

Is that the same in English?

Do you think that it is important to speak English outside of class to practice?

How many times a week do you talk to people in English?

In an average day, do you speak more in English or in Spanish?

Who do you talk to in English?

Prompt: Friends, neighbors, coworkers?

Where do you usually talk to people in English?

Prompt: At home, at church, in stores, at work?

\section{Interaction Experiences}

When do you feel most comfortable speaking in English? (What people, place, time, situation)

What makes you feel comfortable in that situation? 
When do you feel least comfortable?

What makes you feel uncomfortable in that situation?

Is there ever a situation where you have to talk English even though you don't feel comfortable doing it? What do you do to help yourself feel more confident in that situation?

Describe the most recent time that you spoke English outside of class.

Who did you talk to?

Why did you talk to that person?

How did you feel before you talked to that person?

How did you feel while you talked to that person?

How did you feel after you talked to that person?

If you were talking to accomplish a specific task, do you feel that you were successful?

Was the experience that you just described a typical experience of talking in English for you? If no, how are your experiences usually different?

Describe the best experience that you have had speaking English. (Follow prompts above)

Describe the worst experience that you have had speaking English. (Follow prompts above)

How do people respond to you when you speak English? Do you feel that people are encouraging? Discouraging?

Do you remember having an experience when someone responded really positively to you? Can you describe it? 
Do you remember having an experience when someone responded really negatively to you? Can you describe it?

What did you do in response? Have you ever been in a similar situation again?

\section{Self-Evaluation / Comparisons to peers}

How long have you been studying English in the U.S.?

Did you know any English before you came to the US?

Have you put a lot of effort into learning English? What kinds of things have you done?

Do you feel that you are good at speaking English?

What was your goal when you first started taking classes? Was there a reason that you wanted to learn the language or a level that you wanted to reach? Have you reached it? Do you have a different goal now?

How do you feel that your English compares to other students in your class, in the same ESL level as you?

Are there people in your family or do you have friends here that have learned to speak English well? Who are they?

\section{Educational Background}

What year did you take your first English class? And how many classes have you taken since?

How many years did you go to school in Mexico?

What is the highest grade that you completed there?

\section{Choose pseudonym}

I need to call you by a different name in my study to protect your privacy. What name would you like me to use? 